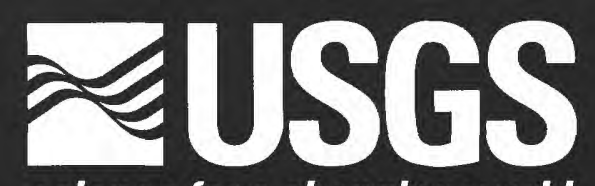

\title{
Diagenesis and Reservoir Quality of the Upper Mississippian Aux Vases Sandstone, Illinois Basin
}

U.S. Geological Survey Professional Paper 1609 


\section{Availability of Publications of the U.S. Geological Survey}

Order U.S. Geological Survey (USGS) publications from the offices listed below. Detailed ordering instructions, along with prices of the last offerings, are given in the current-year issues of the catalog "New Publications of the U.S. Geological Survey."

\section{Books, Maps, and Other Publications}

\section{By Mail}

Books, maps, and other publications are available by mail from-

\section{USGS Information Services}

Box 25286, Federal Center

Denver, CO 80225

Publications include Professional Papers, Bulletins, WaterSupply Papers, Techniques of Water-Resources Investigations, Circulars, Fact Sheets, publications of general interest, single copies of permanent USGS catalogs, and topographic and thematic maps.

\section{Over the Counter}

Books, maps, and other publications of the U.S. Geological Survey are available over the counter at the following USGS Earth Science Information Centers (ESIC's), all of which are authorized agents of the Superintendent of Documents.

- Anchorage, Alaska-Rm. 101, 4230 University Dr.

- Denver, Colorado-Bldg. 810, Federal Center

- Menlo Park, California-Rm. 3128, Bldg. 3, 345 Middlefield Rd.

- Reston, Virginia-Rm. 1C402, USGS National Center, 12201 Sunrise Valley Dr.

- Salt Lake City, Utah-2222 West, 2300 South (books and maps available for inspection only)

- Spokane, Washington-Rm. 135, U.S. Post Office Bldg., 904 West Riverside Ave.

- Washington, D.C.-Rm. 2650, Main Interior Bldg., 18th and C Sts., NW.

Maps only may be purchased over the counter at the following USGS office:

- Rolla, Missouri-1400 Independence Rd.

\section{Electronically}

Some USGS publications, including the catalog "New Publications of the U.S. Geological Survey," are also available electronically on the USGS's World Wide Web home page at http://www.usgs.gov

\section{Preliminary Determination of Epicenters}

Subscriptions to the periodical "Preliminary Determination of Epicenters" can be obtained only from the Superintendent of
Documents. Check or money order must be payable to the Superintendent of Documents. Order by mail from-

Superintendent of Documents Government Printing Office Washington, D.C. 20402

\section{Information Periodicals}

Many Information Periodicals products are available through the systems or formats listed below:

\section{Printed Products}

Printed copies of the Minerals Yearbook and the Mineral Commodity Summaries can be ordered from the Superintendent of Documents, Government Printing Office (address above). Printed copies of Metal Industry Indicators and Mineral Industry Surveys can be ordered from the Center for Disease Control and Prevention, National Institute for Occupational Safety and Health, Pittsburgh Research Center, P.O. Box 18070, Pittsburgh, PA 15236-0070.

\section{Mines FaxBack: Return Fax Service}

1. Use the touch-tone handset attached to your fax machine's telephone jack. (ISDN [digital] telephones cannot be used with fax machines.)

2. Dial (703) 648-4999.

3. Listen to the menu options and punch in the number of your selection, using the touch-tone telephone.

4. After completing your selection, press the start button on your fax machine.

\section{CD-ROM}

A disc containing chapters of the Minerals Yearbook (193395), the Mineral Commodity Summaries (1995-97), a statistical compendium (1970-90), and other publications is updated three times a year and sold by the Superintendent of Documents, Government Printing Office (address above).

\section{World Wide Web}

Minerals information is available electronically at http://minerals.er.usgs.gov/minerals/

\section{Subscription to the Catalog "New Publications of the U.S. Geological Survey"}

Those wishing to be placed on a free subscription list for the catalog "New Publications of the U.S. Geological Survey" should write to-

U.S. Geological Survey

903 National Center

Reston, VA 20192 


\title{
U.S. Department of the Interior \\ Bruce Babbitt, Secretary
}

\author{
U.S. Geological Survey \\ Charles G. Groat, Director
}

For sale by U.S. Geological Survey, Information Services

Box 25286, Federal Center

Denver, CO 80225

Any use of trade, product, or firm names in this publication

is for descriptive purposes only and does not

imply endorsement by the U.S. Government

\section{Library of Congress Cataloging-in-Publication Data}

Pitman, Janet $\mathrm{K}$.

Diagenesis and reservoir quality of the Upper Mississippian Aux Vases Sandstone, Illinois Basin / Janet K. Pitman, Mitchell Henry, and Hannes Leetaru.

p. cm. - U.S. Geological Survey professional paper ; 1609) Includes bibliographical references.

1. Geology, Stratigraphic-Mississippian. 2. Diagenesis-Illinois Basin. 3. Petroleum-Geology-Illinois Basin. 4. Aux Vases Formation. I. Henry, Mitchell E. II. Leetaru, Hannes E.

III. Title. IV. Series.

QE672.P58 2000

$553.2^{\prime} 8^{\prime} 0977-\mathrm{dc} 21$ 


\section{Diagenesis and Reservoir Quality of the Upper Mississippian Aux Vases Sandstone, Illinois Basin}

By Janet K. Pitman, Mitchell Henry, and Hannes Leetaru

U.S. Geological Survey Professional Paper 1609 


\section{Contents}

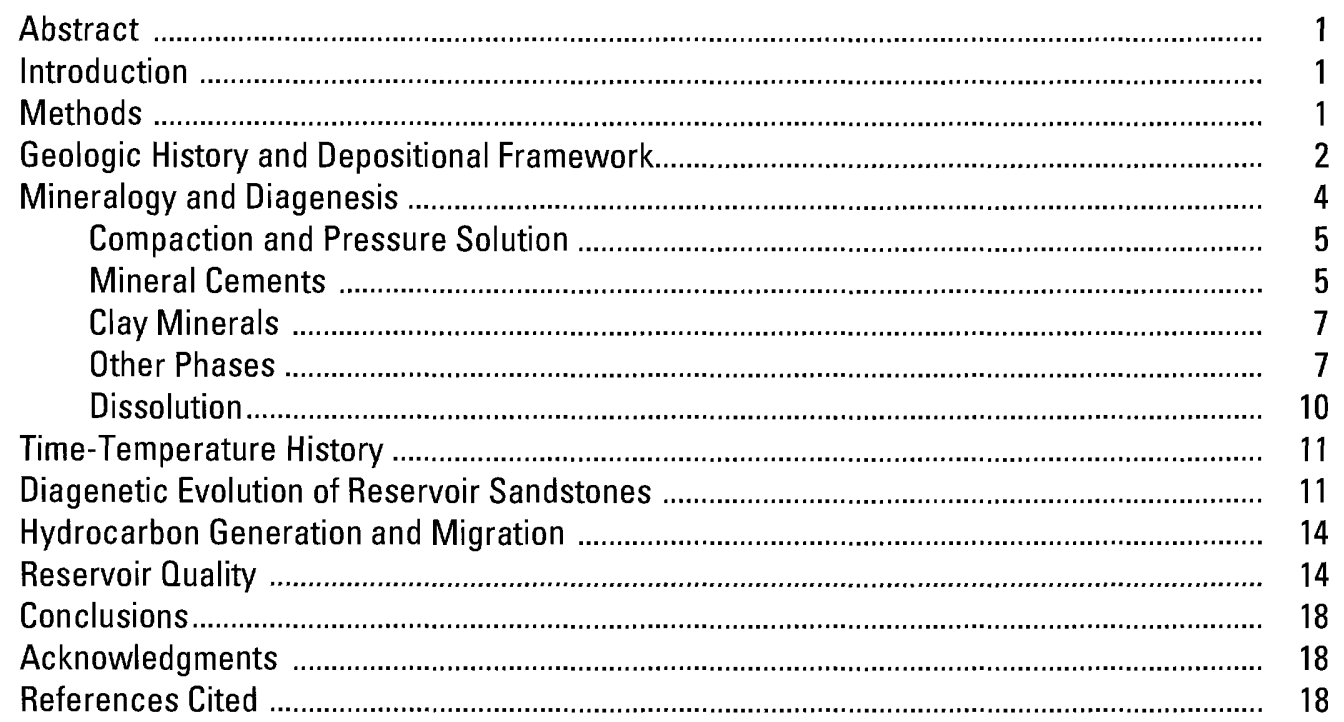

\section{Figures}

1. Location map showing the Illinois Basin and east-west cross section depicting Upper Mississippian Chesterian Series and Upper Devonian and Lower Mississippian New Albany Shale.

2. Map showing location of core holes sampled for petrographic and geochemical analysis.

3. Stratigraphic column depicting the interval between Beech Creek Limestone and St. Louis Limestone

4. Isolith map for the Aux Vases Sandstone ..................................................................

5. Ternary QFL plot for the Aux Vases Sandstone ........................................................ 7

6. Diagram of paragenetic sequence of diagenetic events in the Aux Vases Sandstone

7. Plot of stable-isotope compositions of diagenetic carbonate cements in reservoir sandstones.

8. Graph of relationship between thin-section porosity and total cement................... 11

9. Burial- and thermal-history curves for the Aux Vases Sandstone interval showing relative timing of major diagenetic events in southern and central Illinois 
10-15. Plots showing:

10. Equilibrium relationship between $\delta^{18} 0$ of water, $\delta^{18} 0$ of

early- and late-diagenetic calcite and dolomite, and

crystallization temperature

11. Relationship between percent core porosity and log permeability ................ 14

12. Core porosity versus present depth for sandstones........................................ 14

13. Relationship between compactional and cementational porosity loss in sandstones

14. Percent intergranular volume versus percent thin-section porosity in sandstones.

15. Core permeability versus present burial depth for sandstones.

16. Isocontour maps depicting regional variations in reservoir quality of sandstones in the Aux Vases interval

\section{Tables}

1. Location of well samples

2. Mineralogic composition of Aux Vases sandstones.

3. Stable-isotope compositions of carbonate cements in Aux Vases sandstones. 


\title{
Diagenesis and Reservoir Quality of the Upper Mississippian Aux Vases Sandstone, Illinois Basin
}

\author{
By Janet K. Pitman, ${ }^{1}$ Mitchell Henry, ${ }^{1}$ and Hannes Leetaru ${ }^{2}$
}

\section{Abstract}

The Aux Vases Sandstone (Upper Mississippian) is extensively cored in the Illinois Basin and thus offers the opportunity to study diagenetic processes that occurred under different temperatures and burial conditions. Major diagenetic events observed in the Aux Vases Sandstone interval include (1) precipitation of precompactional illite and grain-rimming chlorite, (2) quartz overgrowth, syntaxial calcite and dolomicrospar cementation, (3) carbonate-cement and framework-grain dissolution, (4) illite and chlorite authigenesis, (5) ankerite precipitation and (6) hydrocarbon emplacement. On the basis of petrographic and stable-isotope analysis, early diagenetic quartz, syntaxial calcite, and dolomicrospar formed at relatively low temperatures $\left(\sim 20^{\circ}-90^{\circ} \mathrm{C}\right)$ in a generally freshwater burial environment, whereas late-diagenetic ankerite precipitated at elevated temperatures $\left(\sim 120^{\circ} \mathrm{C}\right)$ in a diagenetic system dominated by basinal brines. Porosity reduction in sandstones was predominantly caused by mechanical compaction and cementation by carbonate and quartz overgrowths. Enhanced porosity, which is mostly of secondary origin, is due to carbonate cement and frameworkgrain dissolution; only minor primary porosity is preserved by early grain-rimming clay. Secondary porosity was mostly caused by acidic meteoric waters and (or) deep basin brines carrying organic and inorganic acids released during maturation of organic-rich shales. On the basis of burial-thermal reconstruction, sandstone diagenesis took place over a short time interval, culminating in the Late Pennsylvanian to Early Permian when the rocks were at or close to their maximum burial $(\sim 2 \mathrm{~km})$. In southern Illinois, combined igneous and hydrothermal heat transport during the late Paleozoic influenced source-rock maturation and subsequent migration of large amounts of petroleum into reservoir sandstones.

\section{Introduction}

The Illinois Basin is a mature, hydrocarbon-producing province, and most of the oil that has been produced (approximately 60 percent) comes from Upper Mississippian siliciclastic and carbonate rocks (fig. 1). The Aux Vases Sandstone, deposited during

1U.S. Geological Survey, Mail Stop 939, Box 25046, Denver, Colorado, 80225.

${ }^{2}$ Illinois State Geological Survey, 615 East Peabody Drive, Champaign, Illinois, 61820.
Late Mississippian time, is an important reservoir unit that has yielded an estimated 1 billion barrels of oil (Seyler, 1984). To date, the diagenesis and reservoir quality of the Aux Vases generally have been studied on a field basis rather than a regional scale, and potential mechanisms and timing of diagenesis have received little attention. In this study we attempt to (1) document the depositional history and framework mineralogy of major clastic sequences within the Aux Vases Sandstone proper, (2) formulate a generalized diagenetic model and examine the extent to which diagenetic processes affected the reservoir quality of sandstones, (3) construct regional reservoir-quality trends by mapping porosity and permeability variations across the area of deposition, and (4) relate the diagenetic history of the unit to the migration and entrapment of hydrocarbons in the basin. Results of the study revealed that early- and late-diagenetic cements are good indicators of the types of fluids that migrated through the sandstone interval. The processes that controlled porosity enhancement and porosity reduction in potential reservoir units were constrained by identifying the origin and timing of these cements. A knowledge of the major controls on porosity and permeability distribution is necessary in order to develop reliable porosity-prediction models in underdrilled areas of the basin.

\section{Methods}

The regional stratigraphic framework of the Aux Vases Sandstone was defined by the correlation of wireline logs from more than 1,400 wells (Leetaru, 1997). Representative core samples of sandstones were taken from approximately 70 wells for petrographic study (fig. 2; table 1). The wells selected for analysis span a depth interval of $\sim 305-1,000 \mathrm{~m}$ and cover a wide geographic area. Thin sections of the sandstone samples were impregnated with blue epoxy for porosity recognition and stained with a combination of Alizarin red-S and potassium ferricyanide to distinguish $\mathrm{Fe}$-free and $\mathrm{Fe}$-bearing carbonate; thin sections were also stained with sodium cobaltinitrate to aid in the identification of K-feldspar. Three hundred counts were made on each sample to quantify rock composition and thin-section porosity. In this study, the classification scheme of Folk (1974) was modified so that the quartz category consisted of monocrystalline grainspolycrystalline quartz grains were included as rock fragments. Grain size, defined as the long axis of random framework grains, was computed for each sample.

Samples containing end-member carbonate were analyzed for their carbon and oxygen isotopic composition by Global Geochemistry (Canoga Park, Calif.) and Mountain Mass 
Spectrometry (Evergreen, Colo.). Carbon- and oxygen-isotope ratios were obtained by a timed-dissolution procedure based on different reaction rates for chemically distinct carbonate phases (Walters and others, 1972). Upon reaction with phosphoric acid, $\mathrm{CO}_{2}$ gas that was evolved in the first hour was attributed to calcite, and $\mathrm{CO}_{2}$ gas evolved after several hours was assigned to dolomite. Isotope results are reported as the per mil (\%o) difference relative to the PDB (Peedee belemnite) standard using the delta $(\delta)$ notation. Data reproducibility is precise to $\pm 0.2 \%$.

Conventional porosity and permeability analyses from 96 wells that penetrated the Aux Vases Sandstone were compiled into a reservoir-quality database. The data were taken from the Illinois State Geological Survey's Well Inventory System. In order to minimize large variations in porosity and permeability within a well, median values were calculated for the cored interval. Determining a median value for a whole interval rather than a specific facies eliminated problems associated with complex lithogenetic relationships, which are difficult to distinguish on well logs and in drill cores.

\section{Geologic History and Depositional Framework}

The Aux Vases Sandstone was deposited during Late Mississippian time as part of a tidally influenced mixed carbonate-siliciclastic system. The unit is composed of alternating carbonate and siliciclastic rock and is bounded by major sequence boundaries (Leetaru, 1997) (fig. 3). The base of the Aux Vases, which corresponds to the lower sequence boundary, generally is at the top of the Upper Mississippian Ste. Genevieve Limestone, but, in some areas, the Ste. Genevieve has been eroded and the Aux Vases unconformably overlies the Upper Mississippian St. Louis Limestone. Where present, the Upper Mississippian Joppa Limestone forms the lower part of the Aux Vases Sandstone (Leetaru, 1997). The Joppa is composed of thinly interbedded limestone, shale, siltstone, and sandstone and corresponds to a marine transgressive event. No hydrocarbons have been recovered from the Joppa because of the lack of good reservoirs. The principal hydrocarbon reservoirs within the Aux Vases occur in sandstone sequences within the upper part of the unit. The upper part of the Aux Vases is predominantly a siliciclastic unit that was deposited during a marine highstand. A relative drop in sea level followed deposition and resulted in widespread erosion. The upper sequence boundary of the Aux Vases is represented by paleosols, mudcracks, and root traces, which are indicators of this erosional event.

On a regional scale, the Aux Vases Sandstone shows variations that correspond to different depositional environments within the siliciclastic-carbonate system (fig. 4). The Aux Vases in the western part of the study area is dominated by massive, crossbedded sandstone beds that are locally fossiliferous and conglomeratic at their bases. Stratigraphic and sedimentologic studies suggest that these fluvial and estuarine sandstones formed as valley-fill deposits during a period of sea-level change (Leetaru, 1997). At shallow depths, these sandstones are important aquifers; however, they have not been found to contain oil and gas. On the basis of sandstones geometries (fig. 4), the Aux Vases in the central region formed from northeast-southwesttrending offshore bars that were deposited parallel to the paleoshoreline. There is only minor oil production from the Aux

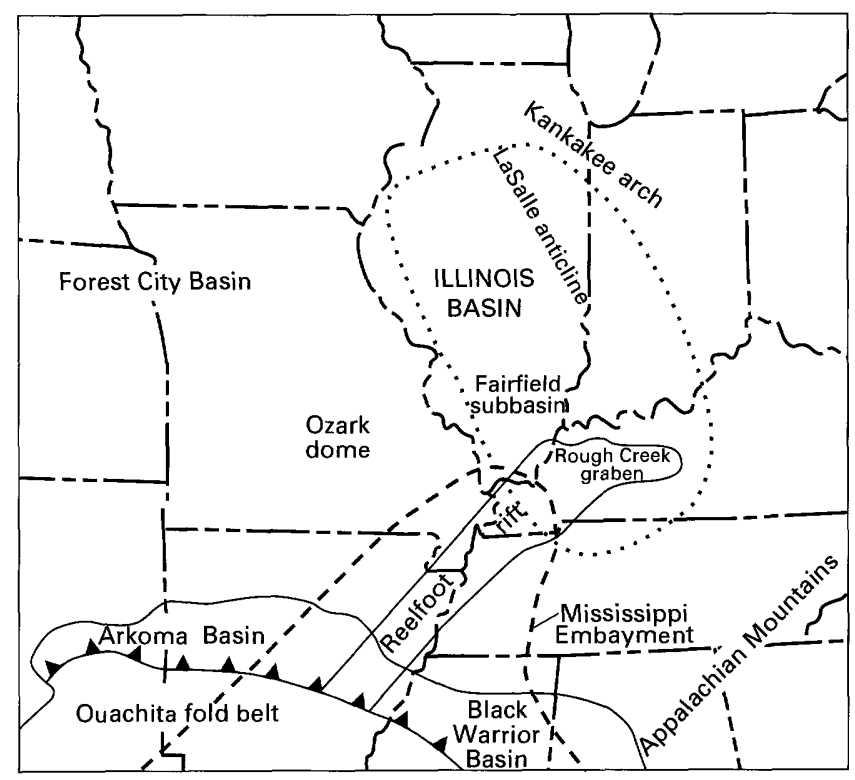

A

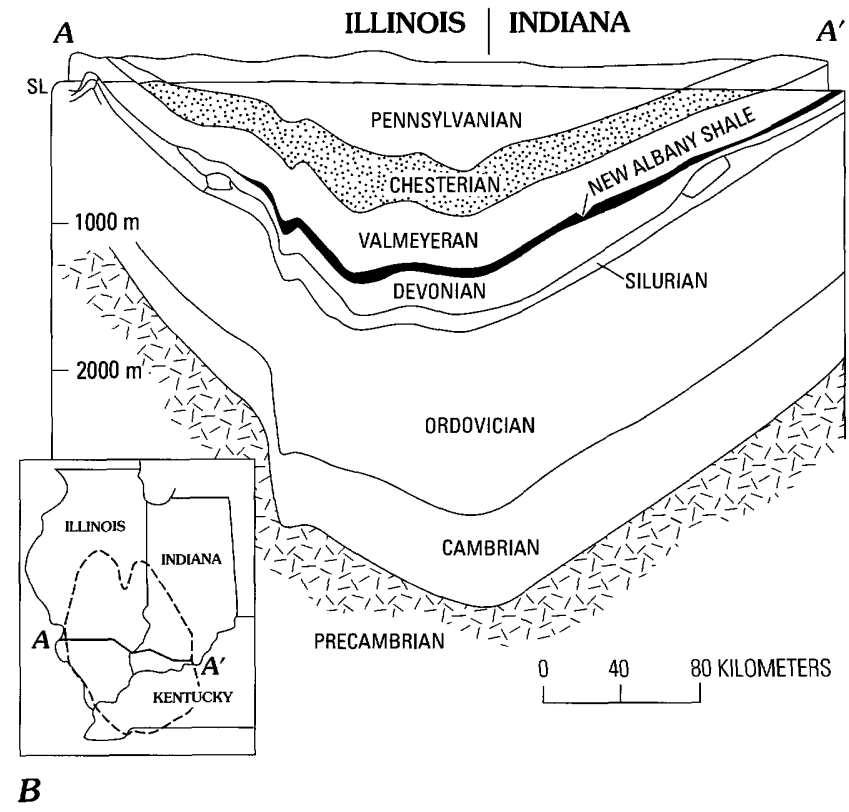

Figure 1. A, Location map showing the Illinois Basin. B, East-west cross section depicting Upper Mississippian Chesterian Series and Upper Devonian and Lower Mississippian New Albany Shale; subcrop of the Chesterian Series is shown as a dashed line on inset map (modified from Swann, 1967).

Vases in this region. Most oil in the Aux Vases is found in a crossbedded sandstone facies in the eastern part of the region. The reservoir facies contains isolated shale clasts and was deposited in a tidally influenced system (Seyler, 1998). In contrast, stratigraphically equivalent nonreservoir sandstones, including rhythmically bedded, and lenticular and flaser-bedded sequences, formed in a tidal-flat environment. The Aux Vases Sandstone generally becomes more calcareous to the east and southeast of the study area, and, at some localities, sandstones were deposited as channels that eroded into the underlying carbonate-rich facies of the 


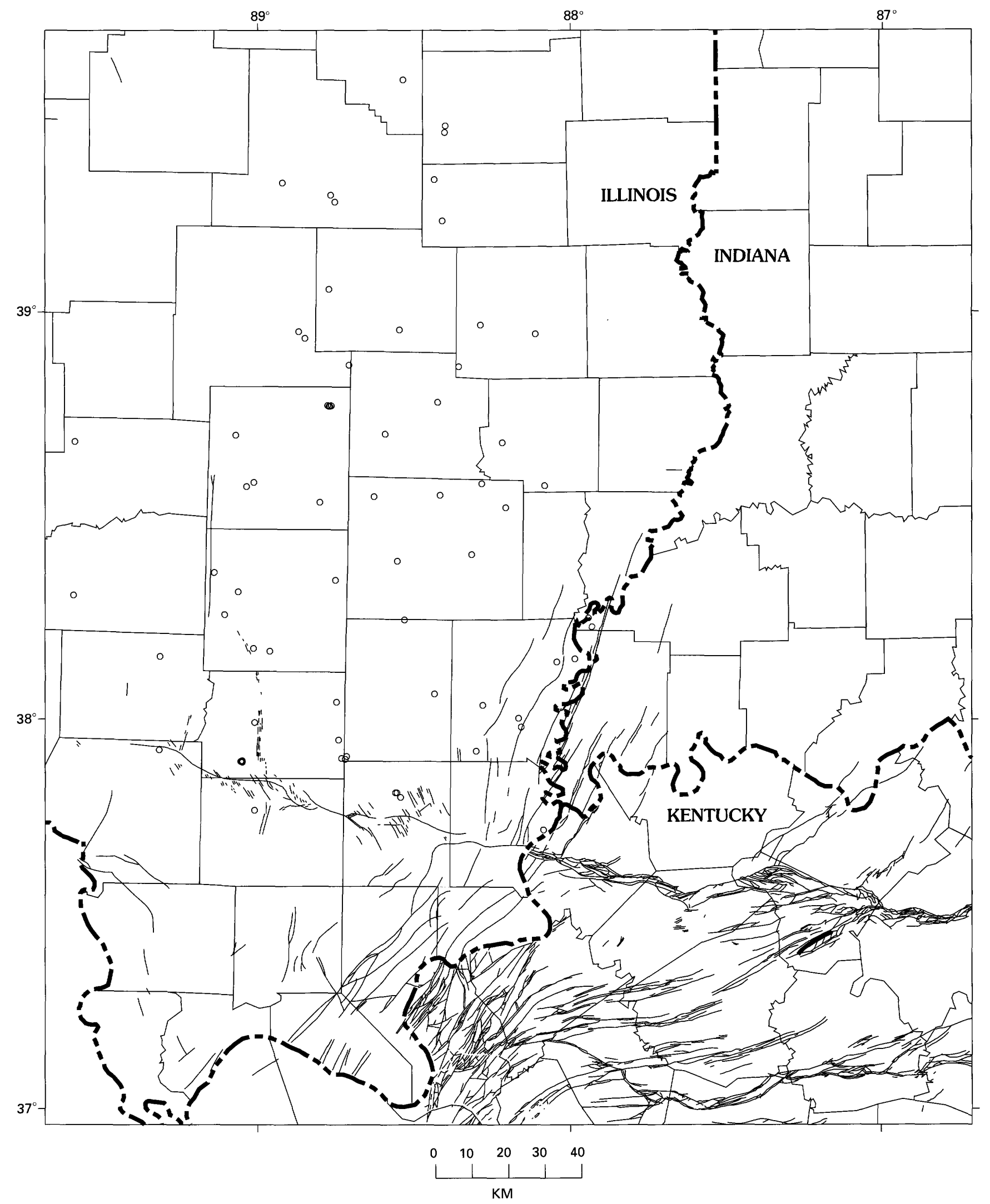

Figure 2. Map showing location of core holes sampled for petrographic and geochemical analysis.

Joppa (Leetaru, 1991). The crossbedded sandstone facies in the eastern region may contain limestone with carbonate grains that were transported into a predominantly siliciclastic environment by storms. These impermeable limestones commonly create lateral and vertical seals that compartmentalize oil reservoirs (Oltz, 1994). Reservoir compartmentalization is recognized by multiple oil-water contacts and higher-than-expected initial flowing pressures within the Aux Vases interval (Leetaru, 1993). 
Table 1. Location of well samples.

\begin{tabular}{|c|c|c|c|c|}
\hline Core ID & API & State & Latitude & Longitude \\
\hline C00071 & 1207700603 & Illinois & 37.928828 & 89.283433 \\
\hline $\mathrm{C} 00285$ & 1214502037 & Illinois & 38.158661 & 89.285138 \\
\hline Co0345 & 1208102322 & Illinois & 38.320668 & 89.042866 \\
\hline C00381 & 1217300063 & Illinois & 39.326528 & 88.916095 \\
\hline C00433 & 1219100109 & Illinois & 38.399507 & 88.544023 \\
\hline $\mathrm{CO0460}$ & 1219306796 & Illinois & 37.933664 & 88.294968 \\
\hline C00467 & 1219304604 & Illinois & 38.160159 & 87.986364 \\
\hline C00494 & 1219100012 & Illinois & 38.556896 & 88.618865 \\
\hline C00592 & 1219300424 & Illinois & 38.153027 & 88.043539 \\
\hline C00597 & 1207900017 & Illinois & 38.878071 & 88.352995 \\
\hline C00598 & 1208100799 & Illinois & 38.174662 & 88.941924 \\
\hline C00606 & 1207900128 & Illinois & 38.980093 & 88.284636 \\
\hline C00627 & 1206500251 & Illinois & 38.073224 & 88.424937 \\
\hline $\mathrm{C} 00674$ & 1206500043 & Illinois & 38.254823 & 88.520667 \\
\hline C00735 & 1212101296 & Illinois & 38.705799 & 89.055451 \\
\hline C00752 & 1215900014 & Illinois & 38.586007 & 88.081222 \\
\hline C00771 & 1207901699 & Illinois & 38.958428 & 88.110717 \\
\hline C00946 & 1212103995 & Illinois & 38.589738 & 88.997243 \\
\hline C00992 & 1218900369 & Illinois & 38.306769 & 89.559301 \\
\hline C01049 & 1213900006 & Illinois & 39.581258 & 88.534095 \\
\hline C01064 & 1212104128 & Illinois & 38.579448 & 89.020696 \\
\hline C01136 & 1205100944 & Illinois & 38.945236 & 88.840027 \\
\hline C01203 & 1219106348 & Illinois & 38.416416 & 88.310185 \\
\hline C01235 & 1204900446 & Illinois & 38.967613 & 88.541509 \\
\hline C01236 & 1205500679 & Illinois & 37.959383 & 88.723707 \\
\hline C01243 & 1219101768 & Illinois & 38.561880 & 88.410092 \\
\hline C01266 & 1205100167 & Illinois & 38.880339 & 88.69996 \\
\hline C01279 & 1205900360 & Illinois & 37.739878 & 88.084803 \\
\hline C01322 & 1202701515 & Illinois & 38.683297 & 89.562707 \\
\hline C01387 & 1219101118 & Illinois & 38.531865 & 88.203934 \\
\hline C01396 & 1208100709 & Illinois & 38.366666 & 89.11894 \\
\hline C01439 & 1208100764 & Illinois & 38.263679 & 89.085271 \\
\hline C01445 & 1219101791 & Illinois & 38.589686 & 88.279198 \\
\hline C01511 & 1204900140 & Illinois & 39.065321 & 88.765539 \\
\hline C01546 & 1202500525 & Illinois & 38.789958 & 88.419539 \\
\hline
\end{tabular}

\section{Mineralogy and Diagenesis}

The Aux Vases Sandstone is predominantly composed of well-sorted to poorly sorted, subangular to subrounded, very fine to medium-grained subarkoses and sublitharenites (fig. 5). Quartzarenites and lithic arkoses also are present within the sandstone interval but in subordinate amounts. Framework-grain compositions of individual sandstones average 81 percent quartz, 9 percent feldspar, and 10 percent rock fragments (table 2). Detrital quartz, the major framework constituent, consists mostly of monocrystalline grains that commonly display small, rounded overgrowths, which suggests that they were derived from reworked, second-cycle sediments. Orthoclase is the dominant feldspar type in the sandstones, but minor amounts of plagioclase feldspar and microcline occur locally. Some feldspar grains have been altered to clay or exhibit a honeycombed (dissolution) texture, whereas other grains have been partially replaced by carbonate cement. Sedimentary rock fragments
Table 1. Location of well samples-Continued.

\begin{tabular}{|c|c|c|c|c|}
\hline Core ID & API & State & Latitude & Longitude \\
\hline C01626 & 1219303068 & Illinois & 38.045577 & 88.27385 \\
\hline C01635 & 1205101009 & Illinois & 38.961306 & 88.860722 \\
\hline C01697 & 1202901120 & Illinois & 39.469346 & 88.398547 \\
\hline $\mathrm{C} 01742$ & 1215900748 & Illinois & 38.691761 & 88.21526 \\
\hline C01813 & 1203500074 & Illinois & 39.337077 & 88.433253 \\
\hline $\mathrm{C} 02055$ & 1212900326 & Illinois & 39.453137 & 88.400827 \\
\hline C02059 & 1212101476 & Illinois & 38.779823 & 88.767094 \\
\hline $\mathrm{CO} 2085$ & 1212104968 & Illinois & 38.779868 & 88.755532 \\
\hline C02096 & 1212101475 & Illinois & 38.778051 & 88.762495 \\
\hline $\mathrm{CO} 2114$ & 1202500549 & Illinois & 38.710497 & 88.584495 \\
\hline $\mathrm{C} 02157$ & 1212104966 & Illinois & 38.778053 & 88.760168 \\
\hline $\mathrm{C} 02170$ & 1212101410 & Illinois & 38.541994 & 88.788652 \\
\hline $\mathrm{C} 02235$ & 1203500090 & Illinois & 39.235724 & 88.407222 \\
\hline $\mathrm{CO} 2253$ & 1219306226 & Illinois & 37.992952 & 88.1545 \\
\hline $\mathrm{CO2323}$ & 1217300392 & Illinois & 39.296958 & 88.76281 \\
\hline $\mathrm{C} 02341$ & 1208100199 & Illinois & 38.181586 & 88.992598 \\
\hline $\mathrm{C} 02521$ & 1216501397 & Illinois & 37.818689 & 88.529178 \\
\hline C03339 & 1205501226 & Illinois & 38.052249 & 88.732005 \\
\hline $\mathrm{C} 04683$ & 1217300078 & Illinois & 39.280430 & 88.74881 \\
\hline C05279 & 1218502475 & Illinois & 38.260543 & 87.944239 \\
\hline C05817 & 1216503280 & Illinois & 37.829886 & 88.540589 \\
\hline $\mathrm{C} 06040$ & 1216503273 & Illinois & 37.829917 & 88.545221 \\
\hline C06069 & 1206503364 & Illinois & 37.918572 & 88.698900 \\
\hline $\mathrm{C} 06071$ & 1206503362 & Illinois & 37.911432 & 88.703276 \\
\hline C13071 & 1205523456 & Illinois & 37.913560 & 88.71468 \\
\hline C13892 & 1219923491 & Illinois & 37.783680 & 88.98479 \\
\hline C13974 & 1205523596 & Illinois & 37.999733 & 88.987413 \\
\hline C13975 & 1219331131 & Illinois & 38.014470 & 88.16316 \\
\hline C13976 & 1205523768 & Illinois & 37.903527 & 89.029376 \\
\hline C13977 & 1205523769 & Illinois & 37.905350 & 89.0246 \\
\hline C14007 & 1205523753 & Illinois & 37.901550 & 89.02454 \\
\hline C14011 & 1205523750 & Illinois & 37.903550 & 89.0269 \\
\hline No \# & 1205523744 & Illinois & 37.903550 & 89.02454 \\
\hline No \# & 1208124399 & Illinois & 38.351390 & 88.73697 \\
\hline IN133 & No data & Indiana & 38.238589 & 87.932857 \\
\hline
\end{tabular}

consisting of chert and carbonate rip-up clasts are common lithic types in sandstones. Bioclastic grains, which also occur in the underlying upper Valmeyeran Series (Pryor and others, 1991), may comprise as much as 15 percent of the whole rock in sandstones adjacent to carbonate beds. Plutonic rock fragments and metamorphic polycrystalline quartz grains are present but in very minor amounts. Heavy minerals-including rutile, tourmaline, and apatite—generally are rare.

On the basis of petrographic analysis, the framework-grain mineralogy of the Aux Vases Sandstone interval remains relatively constant throughout the area of deposition with no distinct variations between individual facies. Outcrop studies and facies analysis suggest that the detrital assemblage was derived from a northwesterly source, possibly the Transcontinental arch or Wisconsin arch; the Ozark uplift also may have been a source for some of the siliciclastic sediment (Leetaru, 1997). In contrast, the Canadian Shield to the north and Appalachian Mountain belt east of the basin are reported to be the source of the sediment in younger Chesterian sandstones, which are also reservoirs for oil 


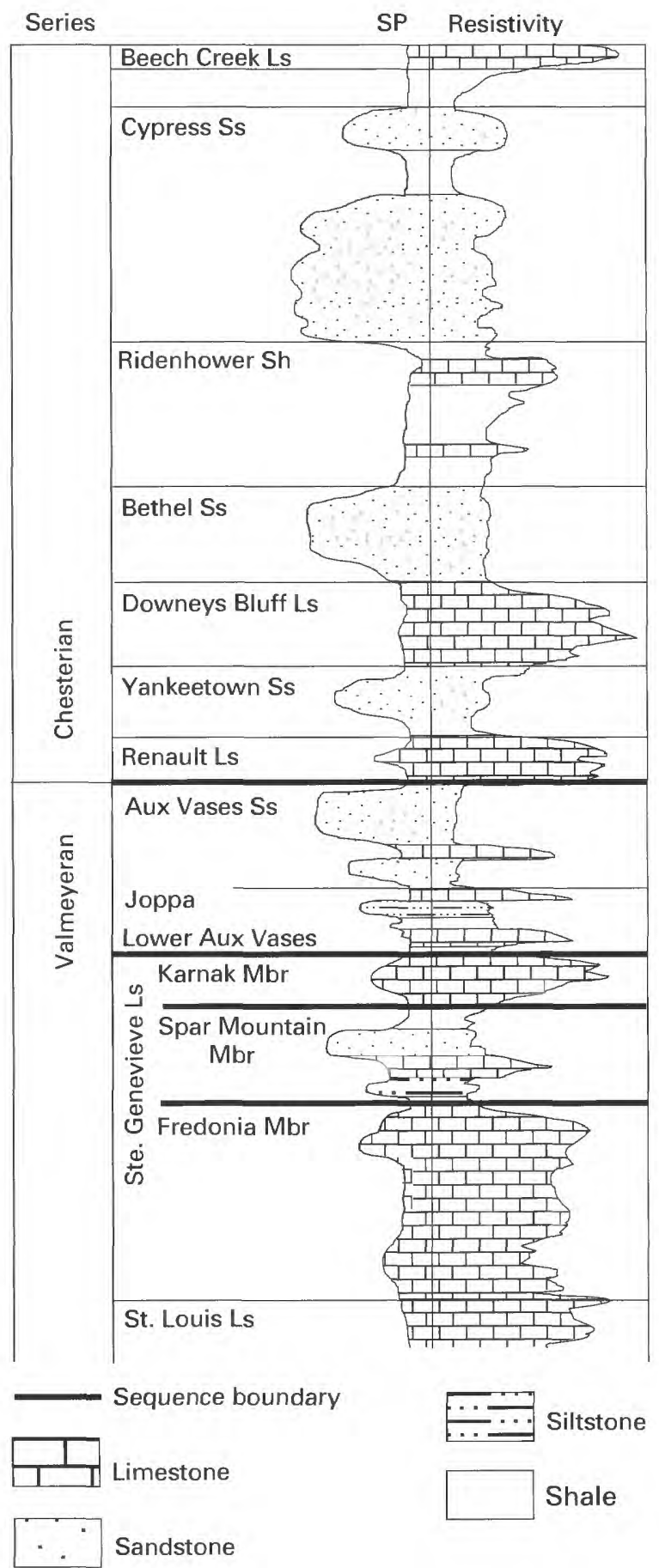

Figure 3. Stratigraphic column depicting the interval between the Beech Creek Limestone and the St. Louis Limestone (modified from Leetaru, 1998).

and gas (Swann, 1963). Our studies indicate that source-area differences are the most likely cause for the variations in framework-grain composition (and subsequent diagenetic alterations) observed in Chesterian-age reservoir sandstones.

The Aux Vases Sandstone was affected by a series of physical and diagenetic alterations during burial that included mechanical compaction, early quartz and carbonate cementation, framework-grain and cement dissolution, clay mineral precipitation, late-diagenetic carbonate development, and hydrocarbon emplacement (fig. 6). On a regional scale, there are no substantial variations in authigenic mineral type or abundance among individual sandstone samples nor are there any obvious depthrelated trends. Minor variations that occur on a local scale most likely reflect the varied lithologies that comprise the unit. It is noteworthy that the paragenetic sequence in the Aux Vases generally is comparable to that found in other Chesterian sandstones despite variations in framework-grain mineralogy (Pitman and others, 1998).

\section{Compaction and Pressure Solution}

Most sandstones in the Aux Vases were affected by mechanical compaction, as indicated by the presence of long and concave-convex grain contacts. In the southern part of the basin, sandstones underwent substantial mechanical compaction, which resulted in only minor early-diagenetic cementation and subsequent dissolution porosity. Compaction in these sandstones occurred by means of increased grain-packing density due to grain rotation and deformation of ductile components. In some parts of the basin, quartz grains display interdigitated, presolved contacts, indicating that they experienced pressure solution. Grain-to-grain contact dissolution is most extensive in finegrained sandstones that contain precompactional, grain-rimming clay. Although pressure solution may occur without clay, clay coats have been shown to accelerate the dissolution process at framework-grain contacts (Heald, 1955; Weyl, 1959).

\section{Mineral Cements}

Total authigenic cement in the Aux Vases Sandstone ranges from approximately 2 percent in the most porous samples to about 48 percent (mean 14 percent) in pervasively cemented beds (table 2). Dominant authigenic mineral cements consist of calcite, dolomite, and quartz. Stable-isotope compositions of the major carbonate phases are reported in table 3 and shown in figure 7.

Calcite and dolomite are the dominant pore-fill cements in reservoir sandstones and are present in amounts ranging from 0 45 percent, mean 7 percent (calcite), and 0-47 percent, mean 6 percent (dolomite) (table 2). On the basis of petrographic analysis, multiple generations of carbonate, including nonferroan and ferroan calcite, dolomicrospar, planar dolospar, and planar ankerite formed during early and late stages of diagenesis. The complex textural relations between individual carbonate phases suggest that other carbonate cements that are not recognized may also occur.

Nonferroan calcite predates other carbonate cements and is most abundant in sandstones containing bioclasts. The syntaxial nature of this calcite indicates that fossil fragments and detrital carbonate grains reworked from nearby carbonate environments served as nucleation sites for early carbonate growth. The carbonand oxygen-isotope compositions of syntaxial calcite vary over a relatively narrow range, from +1.02 to $-3.40 \%$ o $\left(\delta^{13} \mathrm{C}\right)$ and -5.87 to $-8.63 \%\left(\delta^{18} \mathrm{O}\right)$ (table 3 ; fig. 7$)$. In well-cemented sandstones, ferroan calcite comprises optically continuous crystals that form a poikilotopic, pore-fill cement with little to no intergranular porosity. The relatively high intergranular volumes characterizing these rocks (4-40 percent, average 25 percent) suggest that only minor mechanical compaction occurred prior to cementation. 


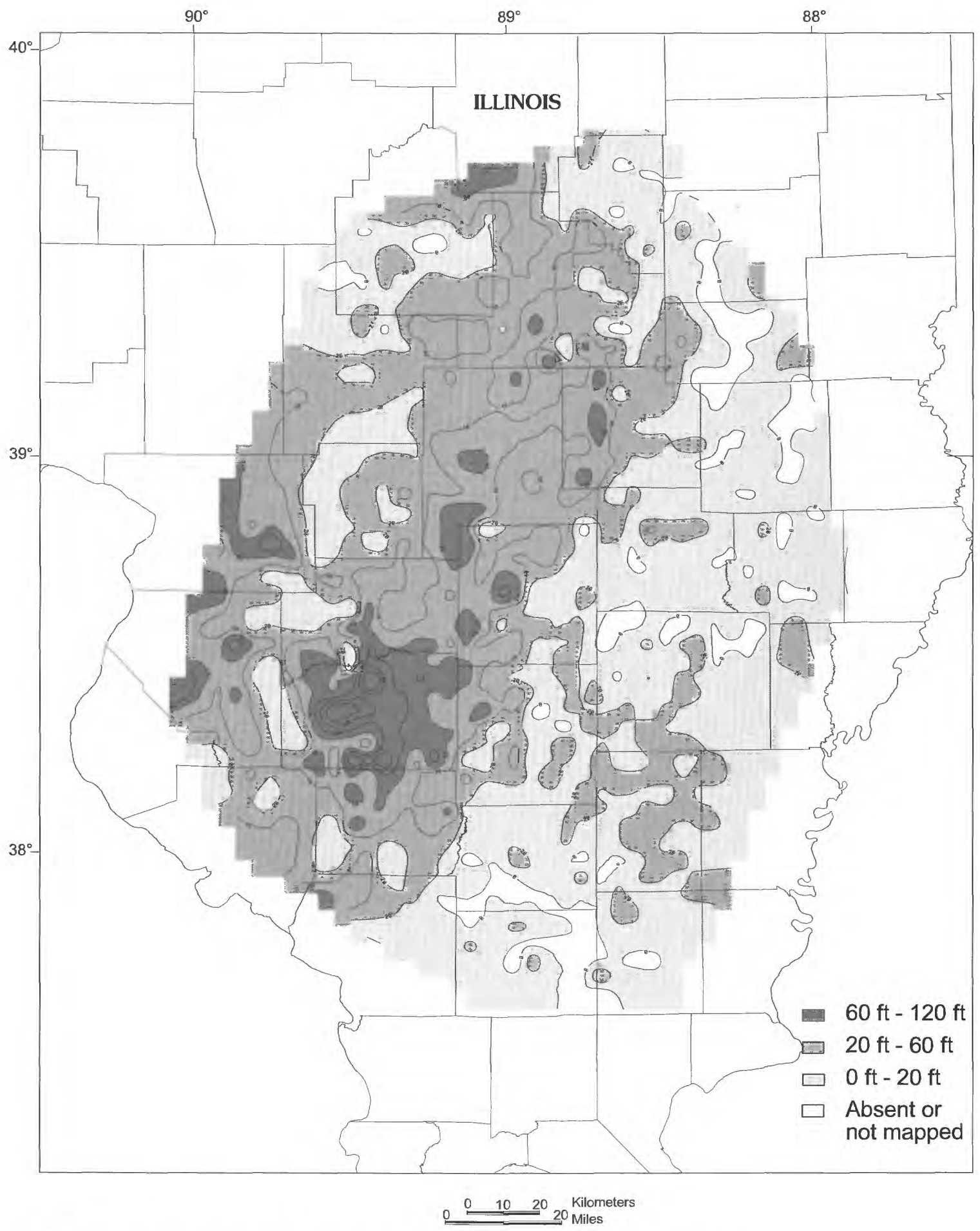

Figure 4. Isolith map for the Aux Vases Sandstone. Contours depict net sand thickness.

More commonly, ferroan calcite has irregular grain boundaries and is distributed in irregular patches, or as remnant cement in sandstones that are porous and permeable. Such features suggest that ferroan calcite formerly may have been more widespread in reservoir sandstones. Locally, ferroan calcite replaces relict nonferroan calcite and is in contact with early quartz overgrowths; ferroan calcite commonly does not replace feldspar. Representative samples of poikilotopic calcite have $\delta^{13} \mathrm{C}$ values ranging from +0.49 to $-0.82 \%$ and $\delta^{18} \mathrm{O}$ values varying from -8.00 to $-8.88 \%$ o (table 3; fig. 7).
Dolomicrospar in reservoir sandstones comprises nonplanar interlocking crystals of nonferroan dolomite and, less commonly, tiny $(\sim 5-25 \mu \mathrm{m})$ planar crystals that occupy primary intergranular pores. The $\delta^{13} \mathrm{C}$ values of dolomicrospar tend to be heavy, from +1.54 to $+0.52 \%$. The $\delta^{18} \mathrm{O}$ values range from -6.51 to $-3.63 \%$ (table 3 ; fig. 7). A large fraction of dolomite in the southern part of the basin is coarse-crystalline $(\sim 20-300 \mu \mathrm{m})$ planar dolospar that may or may not coexist with quartz and calcite. Most planar dolospar forms compositionally homogeneous euhedral crystals but some (detrital?) planar dolospar grains are 


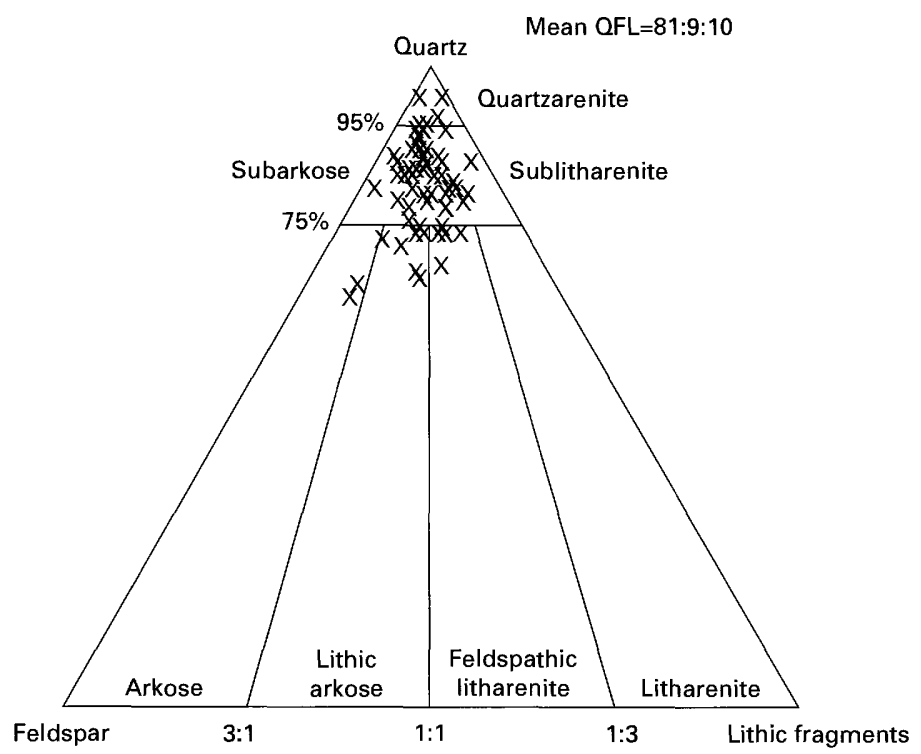

Figure 5. Ternary QFL (quartz, feldspar, lithic fragments) plot for the Aux Vases Sandstone based on the classification of Folk (1974).

partially rounded and exhibit Fe-rich overgrowths. The intergrown nature of planar ferroan and nonferroan dolospar and the small amounts of planar dolospar in most samples prevented stable-isotope analysis of these phases.

Planar ankerite postdates other carbonate cements in reservoir sandstones and is most abundant in southern Illinois in areas that are faulted. Most ankerite occurs as discrete or clustered rhombs with straight boundaries, but in well-cemented sandstones it forms a poikilotopic cement that infills secondary pores and replaces framework grains such as K-feldspar. One sample of planar ankerite analyzed isotopically has values of $+0.04 \%$ o $\left(\delta^{13} \mathrm{C}\right)$ and $-7.58 \%\left(\delta^{18} \mathrm{O}\right)$ (table 3 ; fig. 7$)$. In a few samples, a small component of ankerite is anhedral to subhedral in habit and displays slightly curved crystal faces with broad sweeping extinction, which classify it as saddle ankerite. Unfortunately, it could not be sampled for isotopic analysis.
Authigenic quartz in reservoir sandstones constitutes discrete euhedral overgrowths that are partially developed or embayed. In a few samples, authigenic chlorite and illite are engulfed by quartz overgrowths. Generally, authigenic quartz averages a few percent, but in some coarser grained sandstones, commonly in the vicinity of major bounding faults in the southern portion of the basin, authigenic quartz cement is locally widespread (greater than 10 percent), which resulted in significant porosity reduction.

\section{Clay Minerals}

The clay-mineral assemblage in the Aux Vases Sandstone (0-18 percent, average 3 percent) is composed of illite, interstratified illite-smectite(?), and chlorite. In thin section, discrete clay phases are difficult to distinguish because they tend to be complexly intergrown. Illite and illite-smectite are predominantly precompactional clays that occur as thin tangential coatings on framework grains devoid of grain overgrowths. In sandstones where precompactional illite and illite-smectite are widespread, interdigitated, presolved grain contacts and incipient stylolites are common features. In a few samples, wispy flakes of illite (and chlorite) are engulfed in quartz overgrowths.

Authigenic chlorite occurs as platelets that are oriented perpendicular to detrital grain surfaces and as discontinuous rims that bridge framework grains in sandstones devoid of early secondary quartz overgrowths. In some sandstones with secondary porosity, dispersed chlorite crystals form loose aggregates in residual pores.

\section{Other Phases}

Authigenic phases present in volumetrically minor amounts in the Aux Vases Sandstone include anhydrite, pyrobitumen, hematite, and pyrite. Occurrences of anhydrite vary from scattered patches to individual euhedral crystals that replace earlier formed

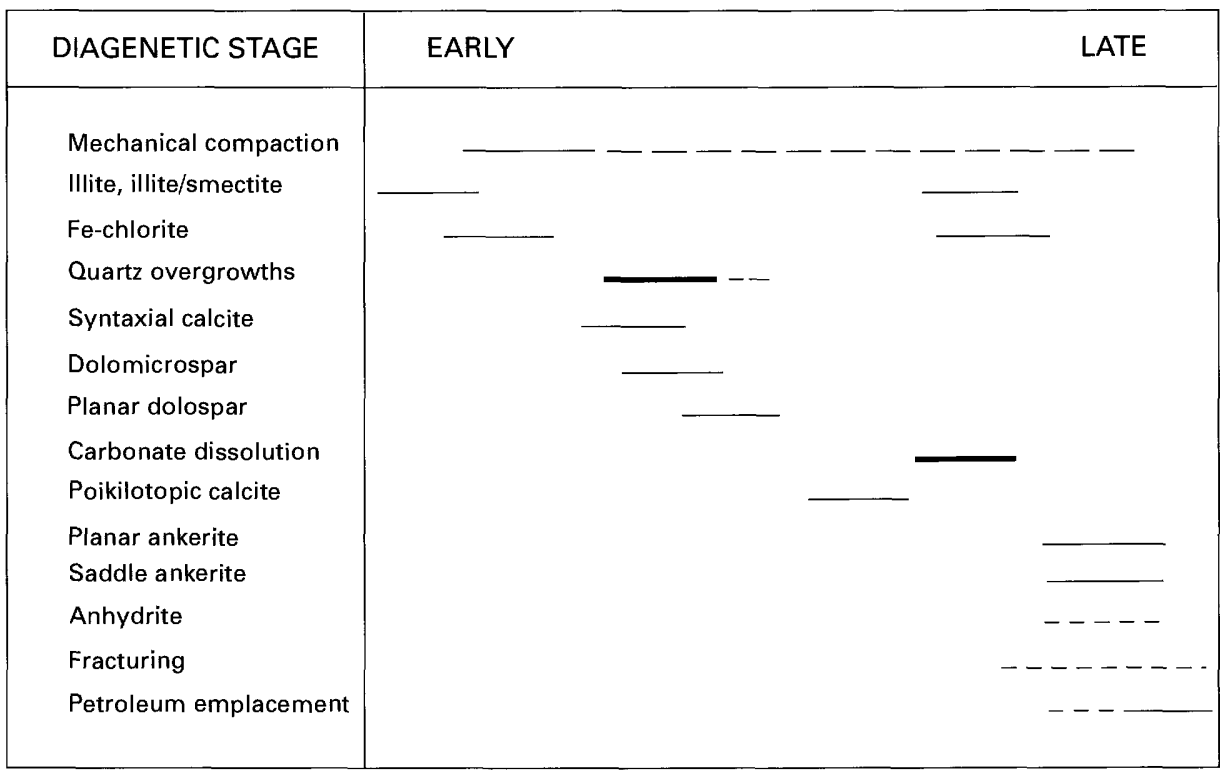

Figure 6. Paragenetic sequence of diagenetic events in the Aux Vases Sandstone. Thick bar represents major period of diagenesis; dashed line indicates probable diagenesis. 
要

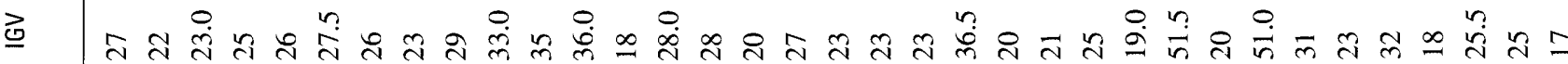

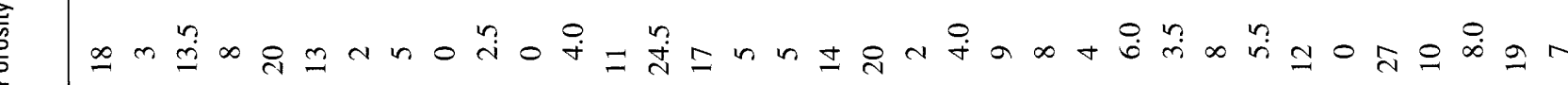

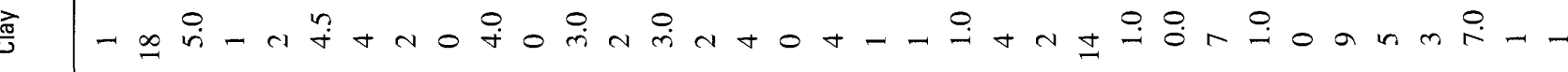
焉

要

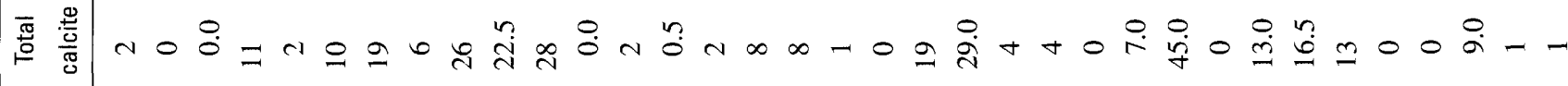
I

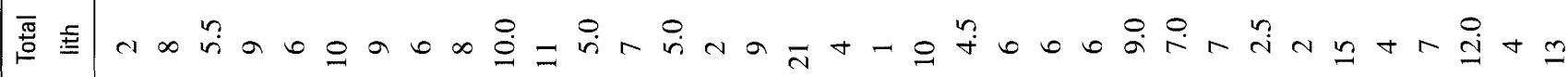
要

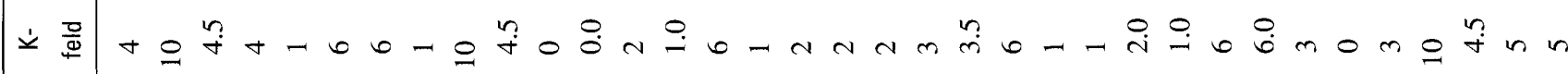

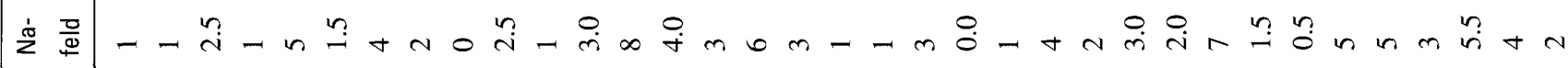

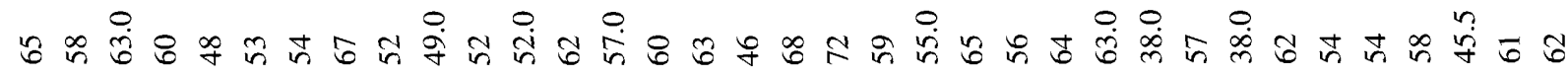

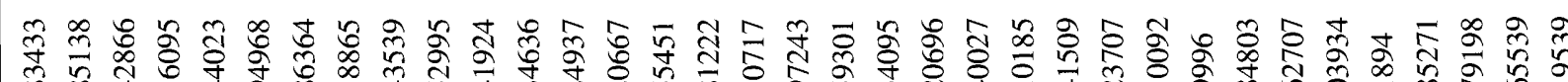

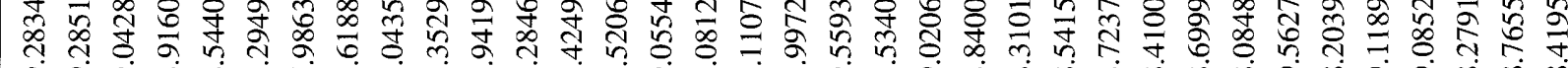

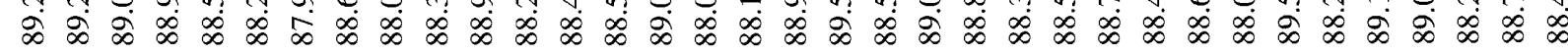

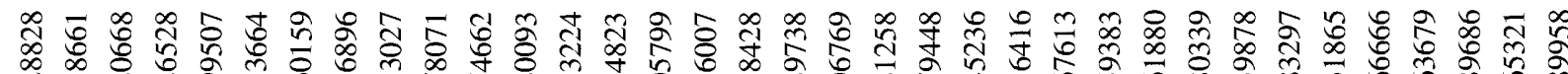
ऊ.

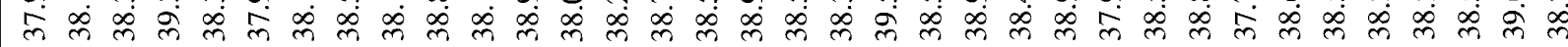

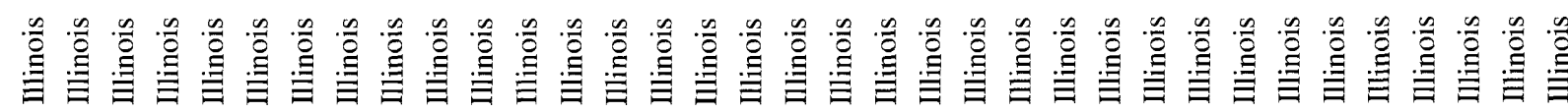




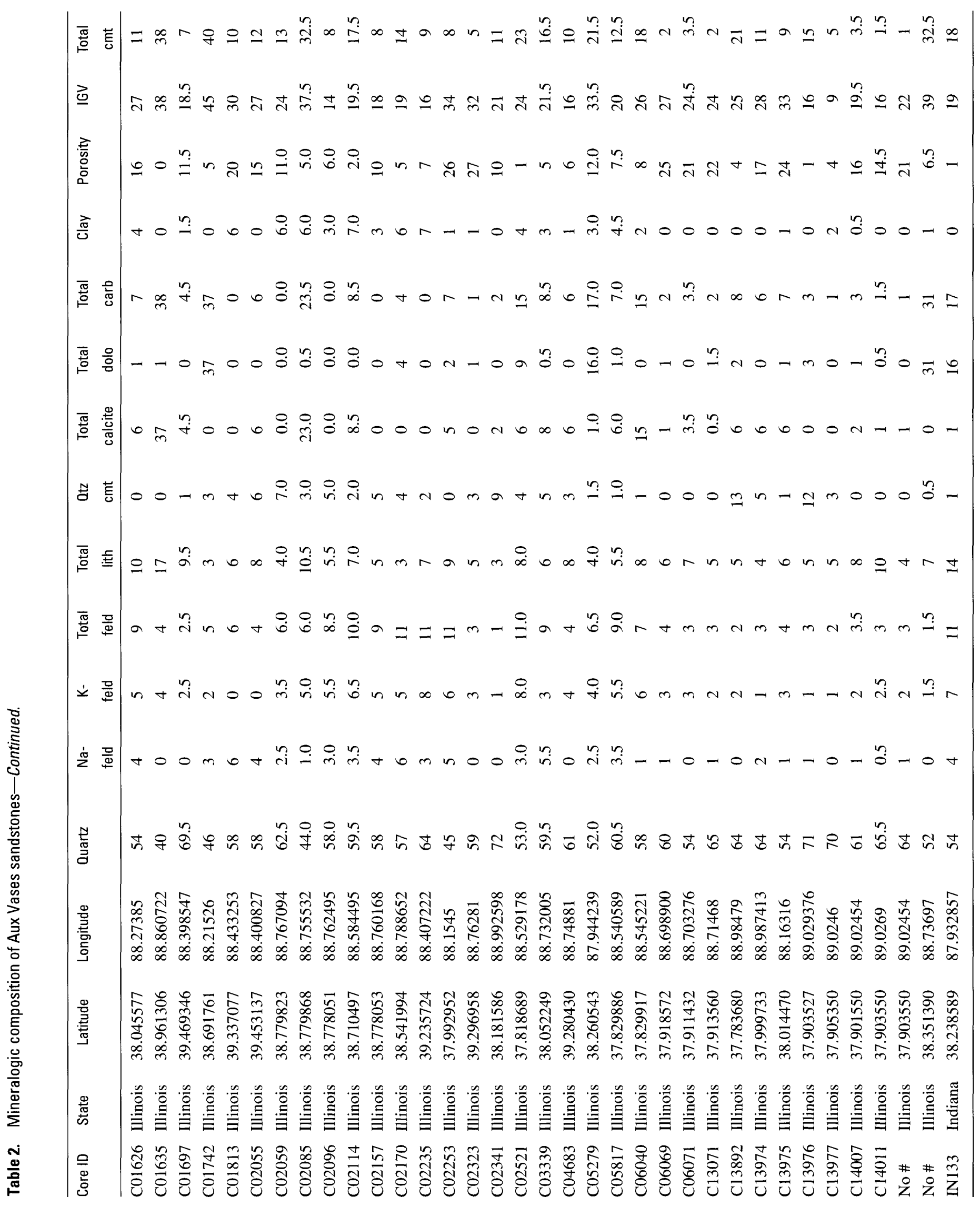


carbonate cements. There is no evidence that anhydrite was affected by dissolution processes or that it was a pervasive cement.

Pyrobitumen is present locally as an opaque material in porous reservoir sandstones. In oil zones, bitumen occupies moldic and secondary intergranular pores and coats authigenic mineral cements. Authigenic minerals in oil-saturated sandstones generally are restricted to minor quartz overgrowths and relic carbonate cement. Fluorescent hydrocarbon inclusions were not observed in any diagenetic phase in the Aux Vases.

\section{Dissolution}

On the basis of visual estimates, approximately 95 percent of the porosity in the Aux Vases Sandstone is intergranular and less than 5 percent of the porosity is intragranular. Thus, in most porous sandstones, intergranular porosity dominates and intragranular porosity is minor. Although some workers have interpreted Chesterian sandstones as dominantly primary porosity reservoirs (Pryor and others, 1991), our studies indicate that most porosity in the Aux Vases sandstone interval is of secondary origin, resulting from the removal of carbonate cement and, to a lesser extent, framework grains, principally feldspar (fig. 8). In thin section, evidence of carbonate-cement dissolution includes embayed quartz overgrowths, well-developed carbonate cement adjacent to extensively leached areas, dissolution voids in tightly cemented sandstones, and relic carbonate cement in otherwise porous sandstones. Petrographic observations indicate that one or more generations of carbonate cement are present in various amounts in some reservoir sandstones, whereas other sandstones are still tightly cemented by carbonate.

Intragranular porosity resulting from partial dissolution of detrital grains is present throughout the Aux Vases Sandstone in

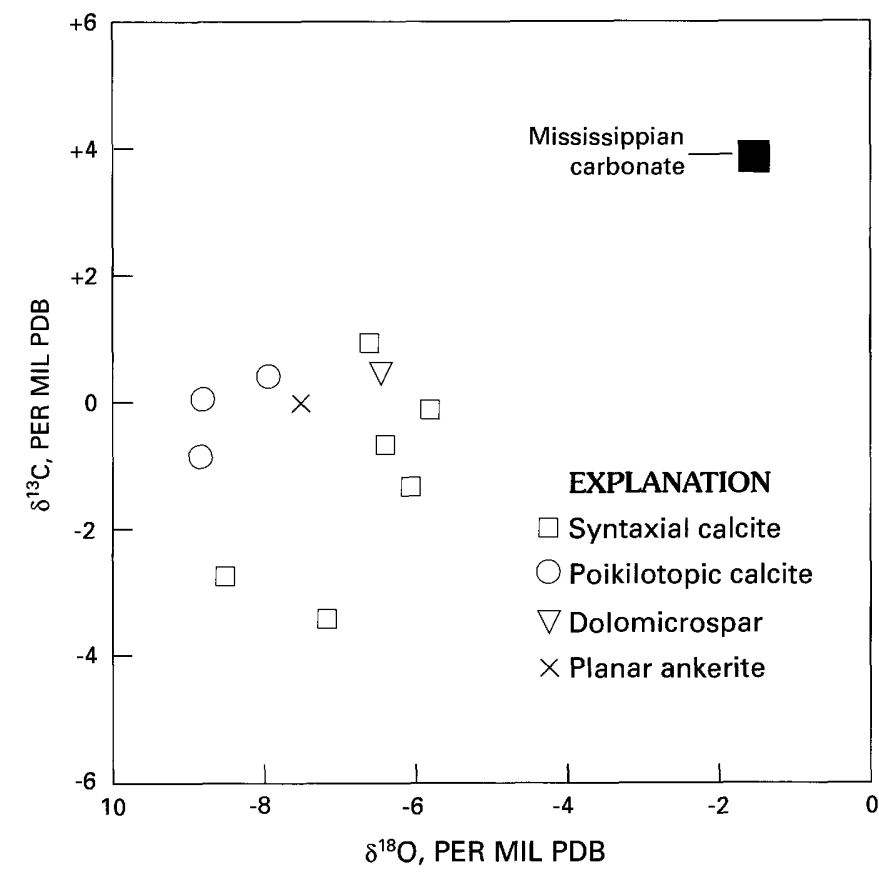

Figure 7. Stable-isotope compositions of diagenetic carbonate cements in reservoir sandstones. Black square represents approximate composition of carbonate cement in equilibrium with Mississippian seawater (from Meyers and Lohmann, 1985). PDB, Peedee belemnite standard.

variable but small amounts. Overall, grain-dissolution porosity did not significantly enhance the total sandstone porosity. Leaching of framework grains affected mainly K-feldspar and resulted in the development of oversized and moldic pores. In sandstones where authigenic clay fills these voids, porosity is moderate and permeability is low.

Table 3. Stable-isotope compositions of carbonate cements in Aux Vases sandstones.

[Values in parentheses are repeat analyses. PDB, Peedee belemnite standard]

\begin{tabular}{lcccc}
\hline Sample ID & State & $\begin{array}{c}\text { Depth } \\
(\mathrm{m})\end{array}$ & $\begin{array}{c}\delta^{13} \mathrm{C} \\
\text { (per mil, PDB) }\end{array}$ & $\begin{array}{c}\delta^{18} 0 \\
\text { (per mil, PDB) }\end{array}$ \\
\hline C0078 & Illinois & 1,946 & $-1.27(-1.29)$ & $-6.14(-6.12)$ \\
C1064 & Illinois & 1,837 & -3.40 & -7.29 \\
C1064 & Illinois & 1,834 & -2.74 & -8.63 \\
C1279 & Illinois & 2,665 & -0.07 & -5.87 \\
C13977 & Illinois & $2,624.9$ & 0.62 & -6.46 \\
C13977 & Illinois & 2,624 & $1.02(0.60)$ & $-6.64(-7.17)$ \\
\hline \multicolumn{5}{c}{ Poikilotopic Fe-calcite } \\
C3339 & Illinois & $3,138.5$ & -0.82 & -8.91 \\
C13362 & Illinois & 3,042 & $0.49(0.49)$ & $-8.00(-8.00)$ \\
\hline C1742 & Illinois & 2,623 & $0.10(0.10)$ & $-8.88(-8.88)$ \\
\hline IN133 & Dolomicrospar & \\
\hline C4399 & Illinois & 2,921 & -3.63 \\
\hline \multicolumn{5}{c}{2,825} \\
\hline
\end{tabular}




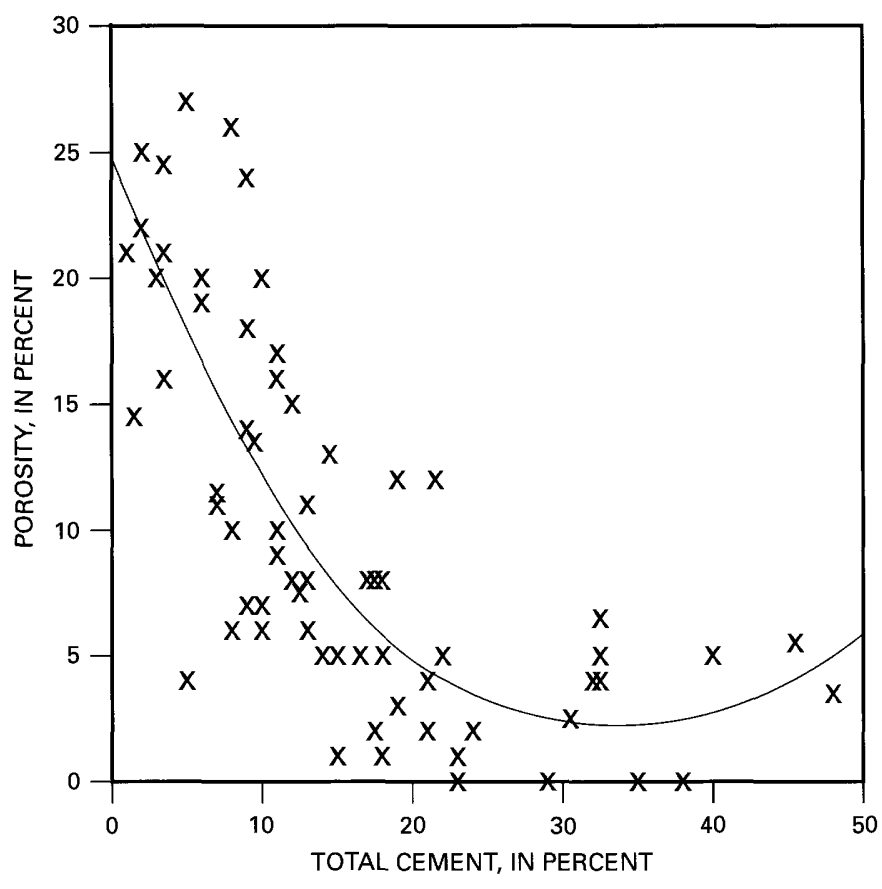

Figure 8. Relationship between thin-section porosity and total cement. The curve is a third-degree polynomial fit to the data.

\section{Time-Temperature History}

Generalized burial- and thermal-history curves of the Aux Vases Sandstone sequence (fig. 9) were generated using the 2dimensional, finite-difference program, Basin2. The burial-thermal model takes into account differences in deposition and erosion, variations in porosity and permeability, and the thermal effects of fluid flow during the basin's history (Bethke and others, 1993). Thermal data incorporated in the model constrained the amount of eroded section in southern lllinois to approximately $1 \mathrm{~km}$. Coupled numerical and heat-flow calculations were used to model paleotemperatures in the Aux Vases Sandstone because they have been shown to reconcile observed biomarker and vitrinite-reflectance maturities, and measured fluid-inclusion homogenization temperatures in the basin fill (Rowan and others, in press). The modeled temperatures based on these calculations (see temperature profile in fig. 9) reflect the strong influence that heat related to late Paleozoic hydrothermal and igneous activity had on the basin's thermal regime during late-stage diagenesis. Hypothetical temperatures calculated for the conductive heatflow model (see fig. 9) are significantly lower than the observed thermal values determined from the rock record (i.e., biomarker and vitrinite maturities, fluid-inclusion temperatures). This suggests that conductive heat flow from the basement played a relatively minor role in the overall thermal history of the basin.

\section{Diagenetic Evolution of Reservoir Sandstones}

In this section, we place the diagenetic processes that may have influenced the reservoir quality of the Aux Vases Sandstone in a time-temperature framework. We then use this framework to constrain our hypothesis that porosity evolution in individual sandstones was controlled by the combined effects of mechanical compaction and mineral cementation.

The evolution of the Aux Vases diagenetic system is shown relative to its time-temperature history in figure 9 . The temperatures that bracket individual diagenetic events were taken from Surdam and others (1989) and correlated with the temperature profile based on igneous and hydrothermal heat flow. The absolute age of individual diagenetic events is difficult to establish because Mississippian sandstones generally lack minerals suitable for isotopic dating; however, the upper limit can be constrained to Early Permian based on the age of peak hydrocarbon generation and migration in the basin (Cluff and Byrnes, 1991).

Sandstones in the Aux Vases were affected by multiple episodes of carbonate-mineral precipitation and dissolution, quartz cementation, and clay-mineral authigenesis. On the basis of petrographic analysis, precipitation of nonferroan and ferroan carbonate began soon after deposition and continued until hydrocarbons were emplaced in the Late Pennsylvanian and Early Permian. The temperature regime during carbonate precipitation varied widely $\left(\sim 30^{\circ}-120^{\circ} \mathrm{C}\right)$ and was governed by the combined effects of burial heat flow, and coupled igneous and hydrothermal heat sources (Pitman and others, 1998). During early burial diagenesis, carbonate formed at low temperatures $\left(\sim 30^{\circ}-80^{\circ} \mathrm{C}\right)$ in a meteoric environment, but later, during deeper burial, it precipitated at elevated temperatures $\left(\sim 80^{\circ}-120^{\circ} \mathrm{C}\right)$ under conditions of high $\mathrm{P}_{\mathrm{CO}_{2}}$ when the pore-water alkalinity might have been buffered by organic acids. Burial-history reconstruction suggests that carbonate precipitation did not occur after Early Permian time (see fig. 9).

The carbonate for calcite and dolomite cements was derived mostly from the dissolution of detrital marine carbonate rock, as indicated by the relatively uniform carbon-isotope compositions of early- and late-diagenetic carbonate cements (average $0.3 \%$; table 3$)$. The narrow range of carbon values $(\sim+1$ to $+3 \%$ ) further suggests recrystallization without $\mathrm{CO}_{2}$ exchange. The later carbonate cements (ferroan calcite and ankerite) formed in a rockbuffered system by remobilization of preexisting cements with little change in $\delta^{13} \mathrm{C}$.

Fractionation equations for calcite and dolomite (Friedman and O'Neil, 1977; Fritz and Smith, 1970) suggest that carbonate in sandstones precipitated in a burial regime that evolved from freshwater to saline conditions over a relatively short period of time. Paleosols, red beds, and root traces near the top of the Aux Vases (Leetaru, 1997) indicate a period of subaerial exposure during which meteoric water infiltrated the sandstone, precipitating the freshwater component of carbonate cement. Petrographic evidence of shallow burial at the time of syntaxial calcite cementation suggests that water of negative oxygen isotope composition was involved in the precipitation of early calcite cement. Assuming early calcite cementation was related to invasion of meteoric water at the end of Aux Vases deposition, burial temperatures probably would have been on the order of $30^{\circ} \mathrm{C}$, which predicts pore-water oxygen-isotope compositions between -3 to $-6 \%$ o SMOW (standard mean ocean water) (fig. 10).

Dolomicrospar, which formed in a shallow burial regime at about the same time as early calcite, is interpreted to have precipitated from waters with $\delta^{18} \mathrm{O}$ values ( -4 to $-7 \%$ SMOW) comparable to those that precipitated calcite (fig. 10). The development of poikilotopic ferroan carbonate postdated the 


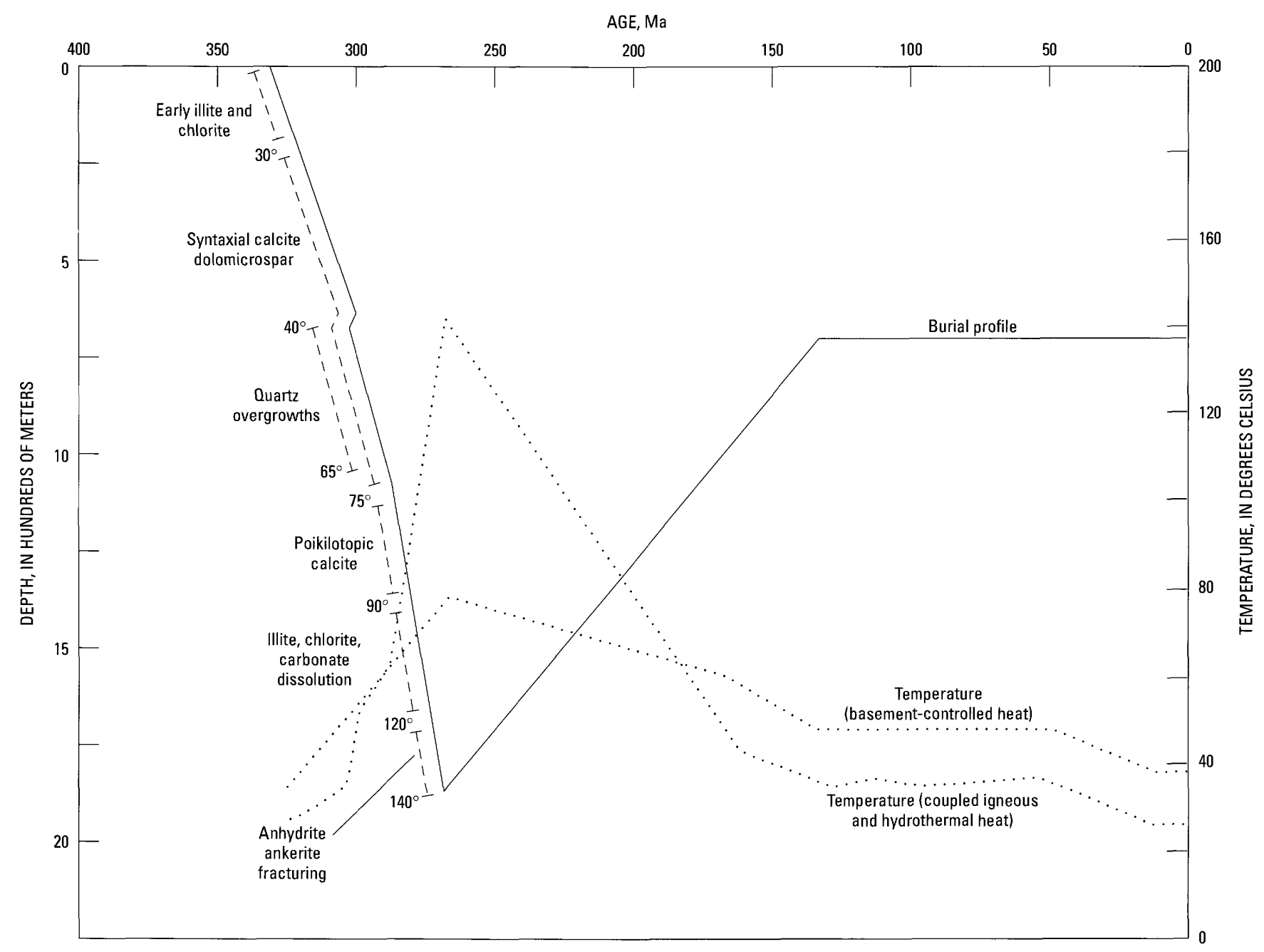

Figure 9. Burial- and thermal-history curves for the Aux Vases Sandstone interval showing relative timing of major diagenetic events in southern and central Illinois. Age of hydrocarbon generation and petrographic features constrain timing of diagenesis. Paleotemperature profiles (igneous plus hydrothermal heat flow and burial-only heat flow) were determined using the coupled fluid-flow and burial heat-flow model, Basin2. Note that thermal curves are depicted relative to geologic age, not burial depth. Temperatures bracketing diagenetic events modified from Surdam and others (1989).

formation of early syntaxial calcite but predated late-stage hydrocarbon emplacement, suggesting precipitation in a burial environment at temperatures as high as $90^{\circ} \mathrm{C}$. Pore-water compositions at a temperature of $90^{\circ} \mathrm{C}$ should be slightly enriched in $\delta^{18} \mathrm{O}$, from +4 to $+3 \%$ o SMOW (fig. 10). Late-diagenetic planar ankerite formed when the sandstone interval was close to its maximum burial depth $(\sim 2 \mathrm{~km})$ and at about the same time that hydrocarbons entered the unit. Assuming crystallization temperatures approximating $120^{\circ} \mathrm{C}$, ankerite formed from reducing, $\delta^{18} \mathrm{O}$-enriched waters with compositions on the order of $+4 \%$ SMOW (fig. 10). Saddle ankerite, also a late-diagenetic phase, may have precipitated from fluids with even heavier values if temperatures as high as $140^{\circ} \mathrm{C}$ were involved in cementation.

On the basis of petrographic observations, most quartz cement in the Aux Vases Sandstone precipitated at shallow burial depths early in the burial history before other mineral cements. In contrast to early quartz, which is the dominant cement in younger Mississippian sandstones, secondary quartz, is a minor diagenetic phase in the Aux Vases compared to early- and late-stage carbonate cements. According to Surdam and others (1989), early quartz overgrowths generally form at fairly low temperatures, which, in the Aux Vases, might have ranged from about $40^{\circ}$ to $65^{\circ} \mathrm{C}$ (see fig. 9). Silica derived from external and internal sources likely was involved in early quartz cementation. As in the early carbonate cement, much of the silica might have originated from saturated meteoric ground waters circulating through the sandstone interval soon after deposition. Upon deeper burial, pressure solution along stylolites and framework-grain contacts might have added additional silica to pore fluids, which subsequently moved by diffusion to nearby sites of precipitation. Incipient stylolitization and grain-to-grain contact dissolution are observed in many sandstones in the Aux Vases and are features commonly associated with thin, illitic clay coats. According to Heald (1955) and Weyl (1959), even though pressure solution at grain contacts can occur without clay, clay coatings tend to accelerate the grain-contact dissolution process, which results in the release of silica into solution for uptake by quartz cement. The presence of interstratified illite and illite-smectite in small yet consistent amounts suggests that the illite-smectite 

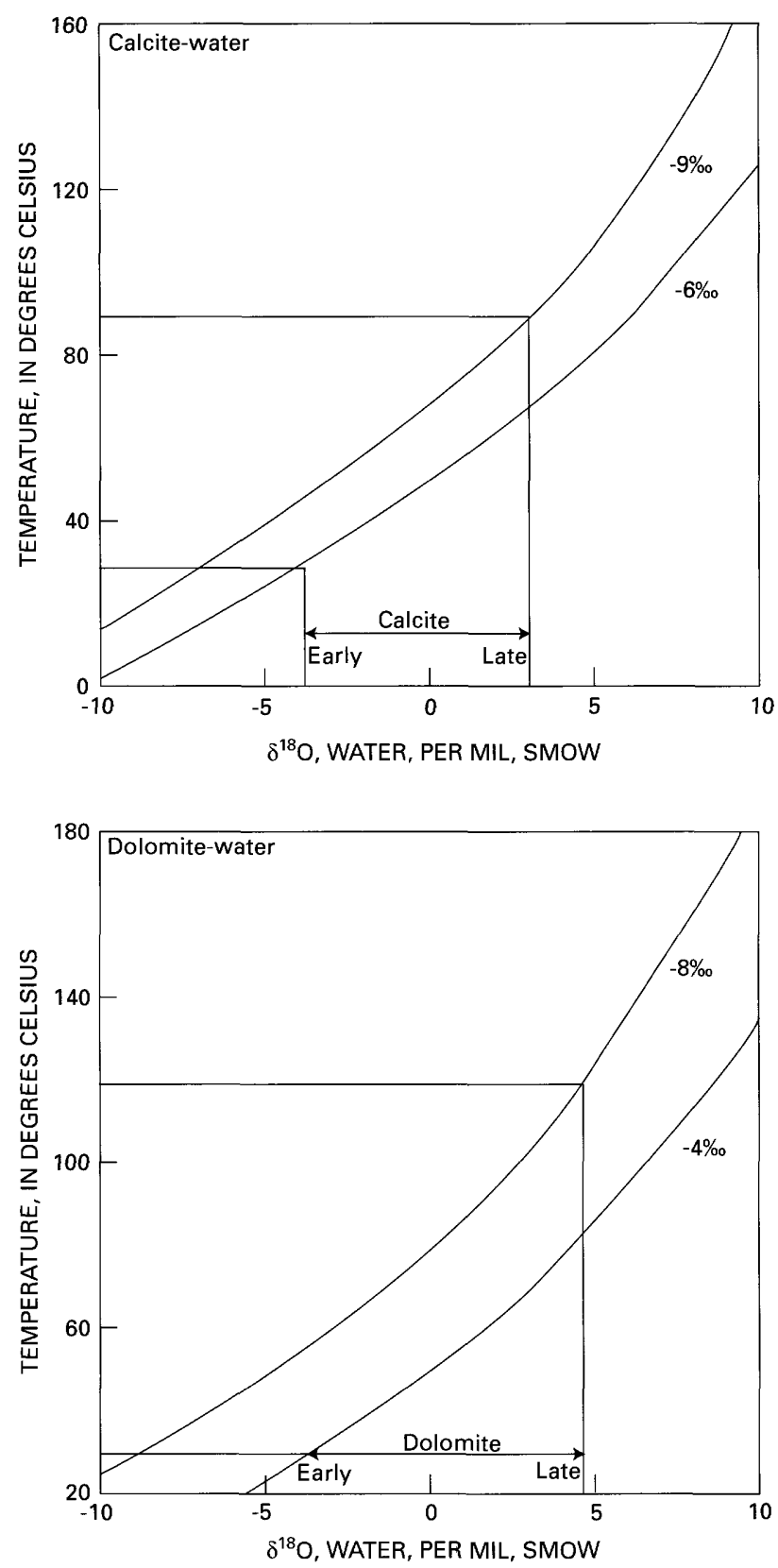

Figure 10. Equilibrium relationship between $\delta^{18} 0$ of water, $\delta^{18} 0$ of early- and late-diagenetic calcite and dolomite, and crystallization temperature. Curves represent locus of temperature and possible $\delta^{18} 0$ of water in equilibrium with a mineral having the indicated oxygen isotopic composition. Fractionation equations (calcite-water: $10^{3} \ln \alpha=2.78 \times 10^{6} \times \mathrm{T}^{-2}-2.89$ and dolomite-water: $\left.10^{3} \operatorname{In} \alpha=2.78 \times 10^{6} \times \mathrm{T}^{-2}+0.11\right)$ are from Friedman and $0^{\prime} \mathrm{Neil}$ (1977) and Fritz and Smith (1970), respectively. SMOW, standard mean ocean water.

transformation process may have contributed minor silica to secondary quartz. Dissolution of framework grains such as feldspar was not a likely source of silica because quartz precipitation generally predated the main stage of framework-grain leaching.

Clay mineral authigenesis in the Aux Vases Sandstone commenced before significant mechanical compaction and continued until late in the burial history (see fig. 9). The earliest formed clays are precompactional illite rims, regarded to be syndepositional or early diagenetic precipitates, and chlorite grain-rimming cement, which formed during shallow burial and before appreciable compaction. Iron oxide grain coatings on some detrital grains and the dewatering of shales may have provided the iron that was incorporated into chlorite. Minor void-filling and grain-replacement illite precipitated following moderate amounts of mechanical compaction. The potassium and silica released into solution upon dissolution of K-feldspar and other framework grains may have been a source of the ions necessary for late-stage illitization.

A combination of processes is required to explain the dissolution of carbonate cement and framework grains, which together account for most of the porosity enhancement in the sandstones studied. In the shallow subsurface, through-flowing meteoric waters generally are acidic and undersaturated with respect to carbonate; thus, they may have been important in the dissolution process. However, in the deeper subsurface, the leaching capacity of meteoric waters is limited because, in addition to being undersaturated with respect to carbonate, the waters tend to be neutralized by reactions along the flow paths.

The Aux Vases Sandstone interval is among the principal reservoirs for hydrocarbons in the Illinois Basin. Thus, it follows that the release of organic acids and the production of $\mathrm{CO}_{2}$ during the early stages of hydrocarbon generation might have been involved in the dissolution of carbonate cement and framework grains. Studies by Carothers and Kharaka (1978) have shown that organic acids are present in formation waters throughout the $80^{\circ}-$ $200^{\circ} \mathrm{C}$ temperature range and dominate the fluid alkalinity at temperatures of $\sim 80^{\circ}-120^{\circ} \mathrm{C}$. Typically, production of organic acids, which reaches a maximum in the $80^{\circ}-100^{\circ} \mathrm{C}$ temperature interval, gradually declines as a result of decarboxylation reactions (Surdam and others, 1989). From $80^{\circ}-100^{\circ} \mathrm{C}$, organic acids buffer the alkalinity at relatively low $\mathrm{P}_{\mathrm{CO}_{2}}$, which increases carbonate solubility, but, at temperatures of about $100^{\circ} \mathrm{C}$, carboxylic acids dominate the fluid alkalinity at a high $\mathrm{P}_{\mathrm{CO}_{2}}$, which are conditions that promote dolomite or ferroan carbonate stability (Surdam and Crossey, 1987; Crossey and others, 1986). The organicinorganic model for clastic diagenesis proposed by Surdam and others (1989) predicts that porosity-producing reactions occur throughout the same temperature range in which organic acids are present in formation waters $\left(\sim 80^{\circ}-120^{\circ} \mathrm{C}\right)$, suggesting that early-formed carbonate cements and framework grains in the Aux Vases Sandstone interval were subject to dissolution. At temperatures approaching $100^{\circ} \mathrm{C}$, iron and aluminum commonly are mobile due to complexing with organic acids, which results in an environment that is generally reducing. Such conditions favor the formation of iron-bearing mineral phases such as ferroan carbonate and chlorite. Some chlorite that formed at temperatures of $100^{\circ} \mathrm{C}$ may have nucleated on early chlorite that developed from clay/iron-oxide rims. In summary, the organic-inorganic model of sandstone diagenesis predicts that dissolution of calcite cement and feldspar followed by the formation of chlorite and dolospar cement took place when the sediments experienced temperatures of $\sim 80^{\circ}-120^{\circ} \mathrm{C}$. Petrographic and stable-isotope data are consistent with this interpretation. 


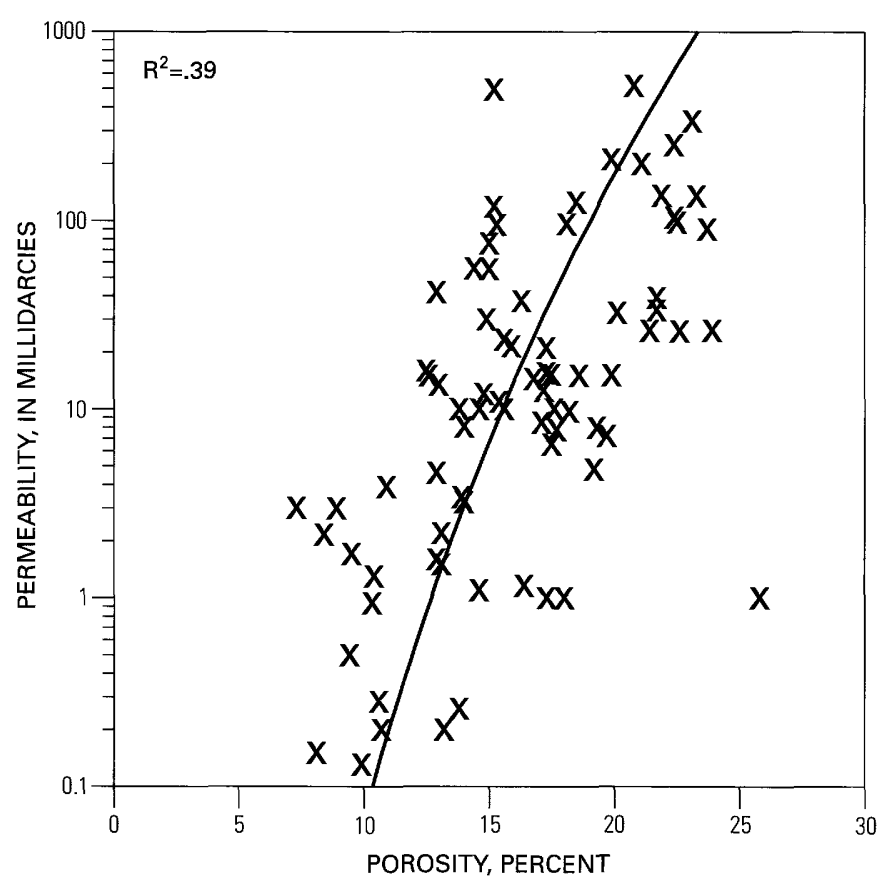

Figure 11. Relationship between percent core porosity and log permeability. $R^{2}$ is the variance of the power curve fit to the data.

\section{Hydrocarbon Generation and Migration}

The entrapment of petroleum generated from source rocks in the Upper Devonian-Lower Mississippian New Albany Shale was the last major diagenetic event that affected reservoir sandstones in the Aux Vases interval (see fig. 9). Petrographic observations suggest that the influx of hydrocarbons into reservoir sandstones inhibited mineral diagenesis in oil zones. In central and southern Illinois, the migration of oil into Aux Vases reservoirs began in the Middle to Late Pennsylvanian and reached its peak when the sedimentary section was close to its maximum burial in the Early Permian. The majority of oil in the Aux Vases Sandstone resides in combination (structural and stratigraphic) traps that overlie (by about $600 \mathrm{~m}$ ) the generative portion of the New Albany Shale (M.D. Lewan, 1997, unpub. data), and the largest fields (i.e., Salem, Clay City, Dale Consolidated) are predominantly associated with faulted anticlines and related structural features that formed or were reactivated during the late Paleozoic (Howard, 1991). The spatial relationship between major oil accumulations in the Aux Vases and mature New Albany source rock suggests that the bulk of the oil moved vertically, by buoyancy, along faults and fractures into lenticular sandstone units and then migrated laterally updip until it reached a sealing unit.

\section{Reservoir Quality}

The Aux Vases Sandstone in the Illinois Basin has wholecore porosities as high as 24 percent, but most samples vary from 4-20 percent (fig. 11). Generally, measured core porosity increases with the log of permeability (fig. 11) but shows no systematic trend with present burial depth (fig. 12), as do other
Chesterian sandstone units in the basin (Pitman and others, 1998). A combination of depositional and diagenetic factors (i.e., grain-size differences, postdepositional alterations) therefore must have influenced porosity preservation in reservoir sandstones.

Whole-core porosities (4-24 percent, median 15 percent) fall within the range of porosities determined in thin section (127 percent, mean 10 percent) but thin-section porosities generally are lower because microporosity (associated with authigenic and detrital clay) is difficult to quantify. Visible porosity in thin section usually classifies as macroporosity; thus, the amount of microporosity in a sandstone sample can be considered to be the difference between core porosity and thin-section porosity. The Aux Vases Sandstone average core porosity differs from thin-section porosity by $\sim 5$ percent, hence microporosity in these rocks may be quantitatively significant.

Intergranular volume (IGV) is a means of evaluating the importance of compaction versus cementation in initial porosity loss in sandstones (Houseknecht, 1987). The IGV in moderately to well-sorted sandstones in the Aux Vases averages 25 percent (fig. 13) and falls within the range of values (24-26 percent) that represents the configuration of grains at closest packing. Several studies have shown that the initial porosities of well-sorted sandstones approximate 40 percent (Beard and Weyl, 1973; Atkins and McBride, 1992; Ehrenberg, 1995). Assuming that depositional porosity in the Aux Vases was on the order of 40 percent, approximately 38 percent of the original porosity was destroyed by mechanical compaction and an additional 36 percent was lost due to mineral cementation (fig. 13). Mechanical compaction and mineral cementation thus were of nearly equal importance in reducing the reservoir quality of sandstones during burial. A comparison of IGV versus thin-section porosity (fig. 14) confirms the interpretation that low-porosity, well-cemented sandstones are no more or less compacted than are the high-porosity, noncemented sandstones. Figure 14 also shows that high-porosity sandstones contain less cement, whereas low-porosity sandstones contain more cement.

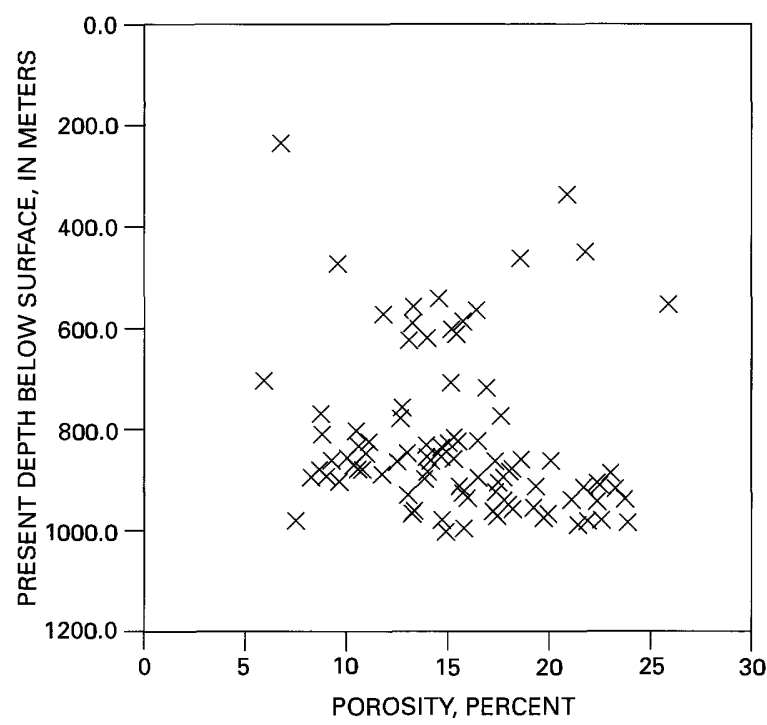

Figure 12. Plot of core porosity versus present depth for sandstones. Note absence of porosity-depth trend. 


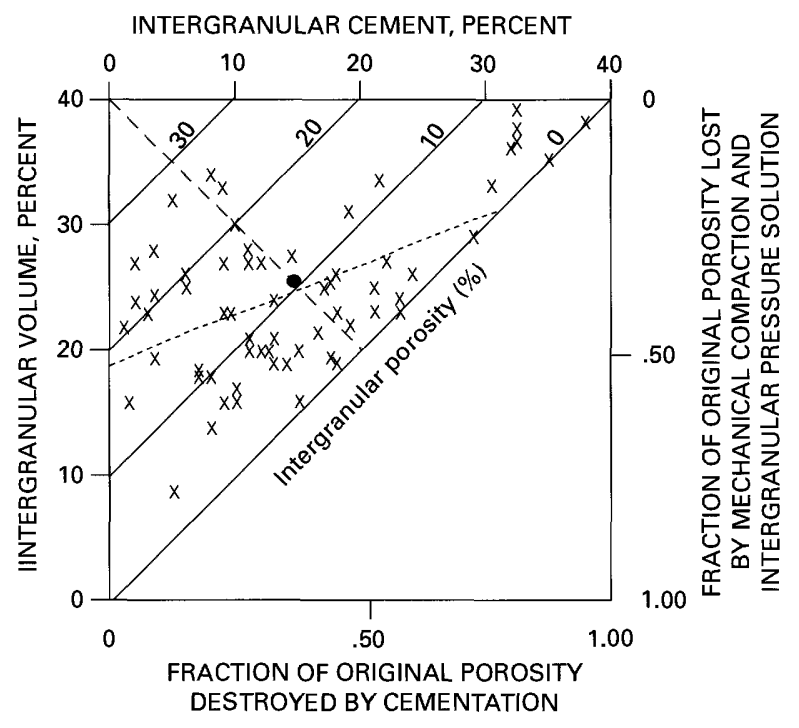

Figure 13. Relationship between compactional and cementational porosity loss in sandstones (after Houseknecht, 1987).

Solid circle is the mean intergranular volume (IGV) value. Shortdashed line represents linear fit to the data.

Core permeability in the Aux Vases Sandstone ranges from 0.1 to about $250 \mathrm{mD}$ and varies markedly at any given depth (fig. 15 ). Variations in permeability likely reflect differences in grain size, total cement volume, and amount of primary versus secondary porosity. As would be expected, the coarser grained sandstones initially had higher permeability than the finer grained sandstones (Beard and Weyl, 1973). According to petrographic observations, some of the original permeability variations due to grain size differences are preserved despite varying degrees of diagenesis subsequent to deposition.

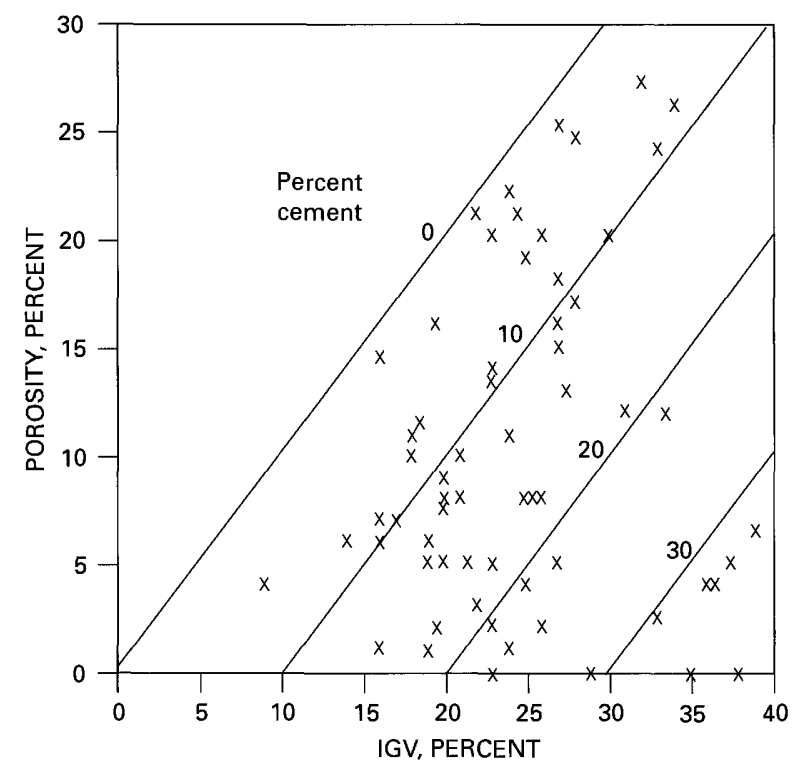

Figure 14. Plot showing percent IGV (intergranular volume) versus percent thin-section porosity in sandstones.

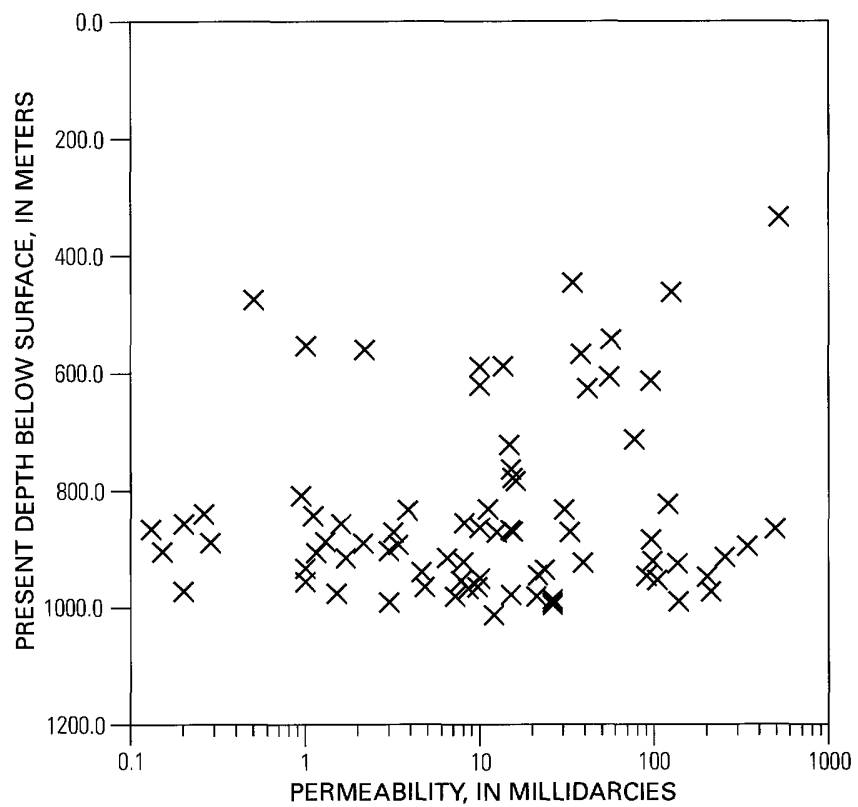

Figure 15. Plot of core permeability versus present burial depth for sandstones.

In well-cemented sandstones, authigenic cements and clays decrease permeability by occluding porosity in intergranular pores. On the basis of textural relations, total cement volume played a greater role in decreasing permeability than did one or more mineral phases alone. For example, sandstones with large amounts of carbonate cement typically have low permeability, but sandstones with little or no carbonate cement also can have low permeability because they have large amounts of secondary quartz. The extent to which clay content affected sandstone permeability is less clear because most samples that have permeability values were not analyzed for their clay content. We speculate that reservoir sandstones with a significant component of detrital and authigenic clay overall have low permeability.

In moderately to highly porous sandstones, higher porosity and permeability correspond to increasing secondary porosity, but primary and secondary porosity are difficult to distinguish; thus, some porosity preserved locally may be of primary origin. In most sandstones, primary pores have better connectivity than secondary pores and should provide a greater contribution to permeability, if present.

Regional variations in porosity and permeability in the Aux Vases Sandstone interval (fig. 16) are generally comparable to the reservoir-quality trends that have been reported for younger Mississippian sandstones in the basin (Pitman and others, 1998).

Porosity and permeability increase in western Illinois, reaching a high of 20 percent and $200 \mathrm{mD}$, and high porosity and permeability occur locally in southwestern Indiana (fig. 16). Reservoir quality in the Aux Vases declines downdip to the south to 4 percent porosity and $50 \mathrm{mD}$ in southern Illinois near the Cottage Grove fault system (fig. 16). On the basis of petrographic observations, sandstone porosity near faults decreases in response to extensive mechanical compaction and diagenetic cementation, whereas, away from faults, porosity significantly increases due to the development of secondary porosity. 


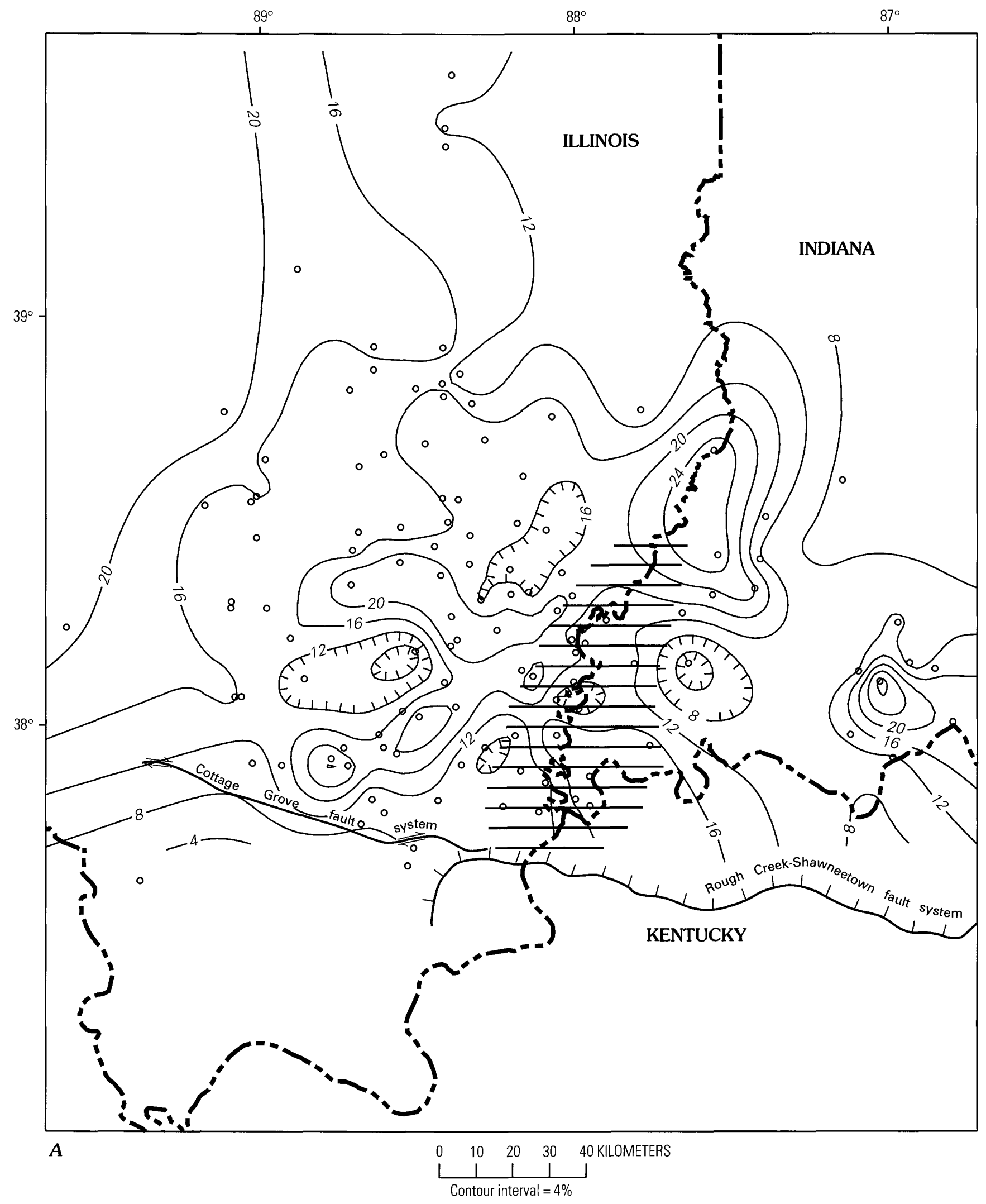

Figure 16 (above and facing page). Isocontour maps depicting regional variations in reservoir quality of sandstones in the Aux Vases interval. Horizontal lines indicate area of Wabash Valley fault system. $A$, percent porosity; $B$, log permeability. 


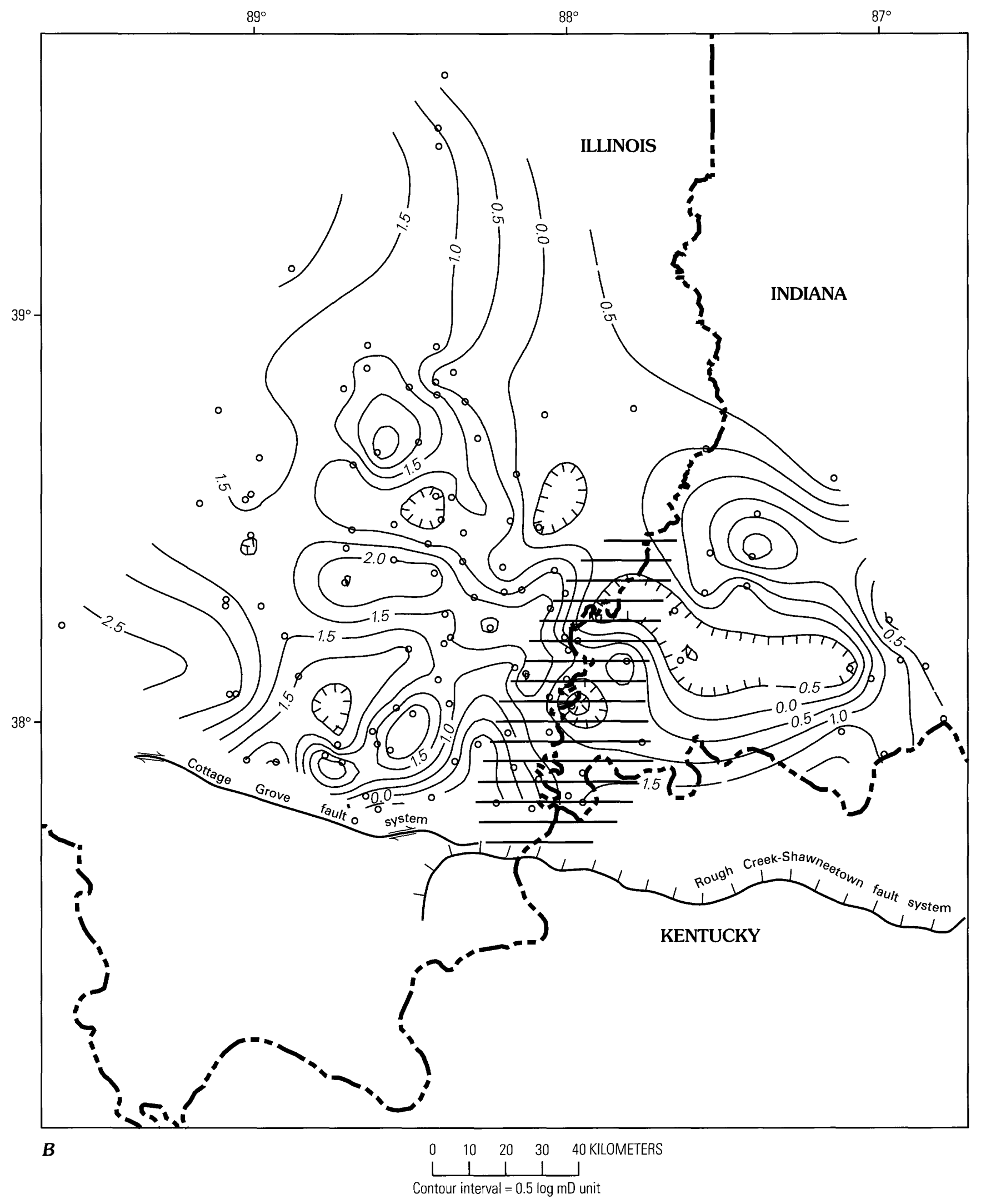




\section{Conclusions}

Diagenetic alteration in the Aux Vases Sandstone began soon after burial in the Late Mississippian and continued until oil entered the sandstones in the Late Pennsylvanian and Early Permian when the rocks were near maximum burial. Major diagenetic events observed in sandstones in the Aux Vases include (1) precipitation of precompactional illite and grain-rimming chlorite, (2) quartz overgrowth, syntaxial calcite, and dolomicrospar cementation, (3) carbonate cement and framework-grain dissolution, (4) illite and chlorite authigenesis, (5) ankerite precipitation, and (6) hydrocarbon emplacement. On the basis of petrographic and stable-isotope analysis, early diagenetic quartz, syntaxial calcite, and dolomicrospar formed at relatively low temperatures $\left(\sim 20^{\circ}-90^{\circ} \mathrm{C}\right)$ in a dominantly freshwater environment, whereas late-diagenetic ankerite precipitated at elevated temperatures $\left(\sim 120^{\circ} \mathrm{C}\right)$ in a diagenetic system dominated by basin brines.

The reservoir quality of the Aux Vases Sandstone varies spatially, ranging from 4 to 24 percent, porosity and 0.1 to 250 $\mathrm{mD}$ permeability. Porosity reduction in sandstones is due to the effects of mechanical compaction and quartz and carbonate cementation, whereas porosity enhancement reflects dissolution of framework grains and carbonate cements. Initially, secondary-porosity development was caused by acidic meteoric waters, but, later, organic acids and $\mathrm{CO}_{2}$ produced during the early stages of hydrocarbon generation promoted more extensive dissolution. The burial-thermal model presented in this study demonstrates that heat associated with igneous activity and heat transported by hydrothermal fluids elevated the basin's heat regime above the level based on normal basement heat flow alone. This added source of heat significantly increased the thermal maturity of organic-matter-rich source rocks, which subsequently resulted in greater rates of hydrocarbon expulsion and oil accumulation in the basin.

The presence of freshwater carbonate and silica cements provides an alternative method of delineating sequence boundaries in marine cratonic basins. Frequently, good evidence for subaerial exposure such as paleosols and root traces are eroded after formation and are not present in core. Results of this study suggest that diagenetic alterations may, at times, be the only evidence of sequence boundaries in the local rock record.

\section{Acknowledgments}

This study was supported by the U.S. Geological Survey's Energy Resources Program in cooperation with the State Geological Surveys of Illinois, Indiana, and Kentucky. The authors are indebted to Marty Goldhaber for generating burial-thermal curves using Basin2. We also are grateful to Joe Hatch and Jim Schmoker for reviewing the manuscript and providing many helpful suggestions.

\section{References Cited}

Atkins, J.E., and McBride, E.F., 1992, Porosity and packing of Holocene river, dune, and beach sands: American Association of Petroleum Geologists Bulletin, v. 76, p. 339-355.
Beard, D.C., and Weyl, P.K., 1973, Influence of texture on porosity and permeability of unconsolidated sand: American Association of Petroleum Geologists Bulletin, v. 57, p. 349-369.

Bethke, C.M., Lee, M-K., Quinodoz, H.A.M., and Kreiling, W.N., 1993, Basin modeling with Basin2, the Hydrogeology Program: UrbanaChampaign, University of Illinois, $225 \mathrm{p}$.

Carothers, W.W., and Kharaka, Y.K., 1978, Aliphatic acid anions in oilfield waters-Implications for the origin of natural gas: American Association of Petroleum Geologists Bulletin, v. 62, p. 2441-2453.

Cluff, R.M., and Byrnes, A.P., 1991, Lopatin analysis of maturation and petroleum generation in the Illinois Basin, in Leighton, M.W., Kolata, D.R., Oltz, D.F., and Eidel, J.J., eds., Interior Cratonic Basins: American Association of Petroleum Geologists Memoir 51, p. 425-454.

Crossey, L.J., Surdam, R.C., and Lahmann, R., 1986, Application of organic/inorganic diagenesis to porosity prediction, in Gautier, D.L., ed., Roles of Organic Matter in Sediment Diagenesis: Society of Exploration Paleontologists and Mineralogists Special Publication 38, p. 147-156.

Ehrenberg, S.N., 1995, Measuring sandstone compaction from modal analyses of thin sections: How to do it and what the results mean: Journal of Sedimentary Research, v. A64, p. 369-379.

Folk, R.L., 1974, Petrology of Sedimentary Rocks: Austin, Texas, Hemphill, $182 \mathrm{p}$.

Friedman, I., and O'Neil, J.R., 1977, Compilation of stable isotope fractionation factors of geochemical interest, in Fleischer, M., ed., Data of Geochemistry, (6th ed.): U.S. Geological Survey Professional Paper 440-KK, 12 p.

Fritz, P., and Smith, D.C.W., 1970, The isotopic composition of secondary dolomite: Geochimica et Cosmochimica Acta, v. 34, p. 1161-1173.

Heald, M.T., 1955, Stylolites in sandstones: Journal of Geology, v. 63, p. 101-114.

Houseknecht, D.W., 1987, Assessing the relative importance of compactional processes and cementation to the reduction of porosity in sandstones: American Association of Petroleum Geologists Bulletin, v. 71, p. 633-642.

Howard, R.H., 1991, Hydrocarbon reservoir distribution in the Illinois Basin, in Leighton, M.W., Kolata, D.R., Oltz, D.F., and Eidel, J.J., eds., Interior Cratonic Basins: American Association of Petroleum Geologists Memoir 51, p. 299-329.

Leetaru, H.E., 1991, Reservoir heterogeneity and improved oil recovery of the Aux Vases (Mississippian) Formation at King field, Jefferson County, Illinois: Illinois Petroleum, v. 135, 49 p.

Leetaru, H.E., 1993, Reservoir heterogeneity and improved oil recovery of the Aux Vases (Mississippian) Formation at Boyd field, Jefferson County, Illinois: Illinois Petroleum, v. 142, 30 p.

Leetaru, H.E., 1997, Sequence stratigraphy and resource assessment of Aux Vases Sandstone in Illinois: Champaign, University of Illinois, Ph.D. dissertation, $161 \mathrm{p}$.

Leetaru, H.E., 1998, Sequence stratigraphy and regional geology of the Aux Vases Sandstone, chap. C of Leetaru, H.E., Seyler, B. and Morse, D.G., organizers, Focused Technology Workshop: Petroleum Resources of the Aux Vases Sandstone, Marion, Illinois: Champaign, Illinois, Illinois State Geological Survey and Midwest Office of the Petroleum Technology Transfer Council, p. C1-C20.

Meyers, W.J., and Lohmann, K.C., 1985, Isotope geochemistry of regionally extensive calcite cement zones and marine components in Mississippian limestones, New Mexico, in Schneidermann, N., and Harris, P.M., eds., Carbonate Cements: Society of Economic Paleontologists and Mineralogists Special Publication 36, p. 223-239. 
Oltz, D.F., 1994, Improved and enhanced oil recovery in Illinois through reservoir characterization: U.S Department of Energy Final Report, DE-FG22-89BC14250.

Pitman, J.K., Henry, M., and Seyler, B., 1998, Reservoir quality and diagenetic evolution of Upper Mississippian rocks in the Illinois Basin: Influence of a regional hydrothermal fluid-flow event during late diagenesis: U.S Geological Survey Professional Paper 1597, 24 p.

Pryor, W.A., Lambourg, A.D., Roberts, M.J., Tharp, T.C., and Wilsey, W.L.M., 1991, Geologic controls on porosity in Mississippian limestone and sandstone reservoirs in the Illinois Basin, in Leighton, M.W., Kolata, D.R., Oltz, D.F., and Eidel, J.J., eds., Interior Cratonic Basins: American Association of Petroleum Geologists Memoir 51, p. 329-359.

Rowan, E.L., Goldhaber, M.B., and Hatch, J.R., in press, The role of regional fluid flow in the Illinois Basin's thermal history: Constraints from fluid inclusions and the maturity of Pennsylvanian coals: American Association of Petroleum Geologists Bulletin.

Seyler, B.J., 1984, Role of diagenesis in formation of stratigraphic traps in Aux Vases of Illinois Basin [abs.]: American Association of Petroleum Geologists Bulletin, v. 68; p. 526-527.

Published in the Central Region, Denver, Colorado

Manuscript approved for publication January 14, 1999

Edited by Richard W. Scott, Jr.

Graphics prepared by Norma J. Maes, David G. Walters, and Carol A. Quesenberry. Use made of author-drafted material Photocomposition by Carol A. Quesenberry
Seyler, B., 1998, Geologic and engineering controls on Aux Vases Sandstone reservoirs in Zeigler field, Illinois: Illinois Petroleum, v. 153, 79 p.

Surdam, R.C., and Crossey, L.J., 1987, Integrated diagenetic modeling: A process-oriented approach for clastic systems: Annual Reviews, Earth and Planetary Sciences, v. 15, p. 141-170.

Surdam, R.C., Crossey, L.J., Hagen, E.S., and Heasler, H.P., 1989, Organicinorganic interactions and sandstone diagenesis: American Association of Petroleum Geologists Bulletin, v. 73, p. 1-23.

Swann, D.H., 1963, Classification of Genevievian and Chesterian (Late Mississippian) rocks of Illinois: Illinois State Geological Survey Report of Investigation 216, $91 \mathrm{p}$.

Swann, D.H., 1967, A summary geological history of the Illinois Basin, in Geology and Petroleum Production of the Illinois Basin: Illinois Geological Society, p. 3-21.

Walters, L.J., Claypool, G.E., and Choquette, P.W., 1972, Reaction rates and $\delta^{18} 0$ variation for the carbonate-phosphoric acid preparation method: Geochimica et Cosmochimica Acta, v. 36, p. 129-140.

Weyl, P.K., 1959, Pressure solution and the force of crystallization: A phenomenological theory: Journal of Geophysical Research, v. 64, p. 2001-2025. 



\section{Selected Series of U.S. Geological Survey Publications}

\section{Books and Other Publications}

Professional Papers report scientific data and interpretations of lasting scientific interest that cover all facets of USGS investigations and research.

Bulletins contain significant data and interpretations that are of lasting scientific interest but are generally more limited in scope or geographic coverage than Professional Papers.

Water-Supply Papers are comprehensive reports that present significant interpretative results of hydrologic investigations of wide interest to professional geologists, hydrologists, and engineers. The series covers investigations in all phases of hydrology, including hydrogeology, availability of water, quality of water, and use of water.

Circulars are reports of programmatic or scientific information of an ephemeral nature; many present important scientific information of wide popular interest. Circulars are distributed at no cost to the public.

Fact Sheets communicate a wide variety of timely information on USGS programs, projects, and research. They commonly address issues of public interest. Fact Sheets are generally two or four pages long and are distributed at no cost to the public.

Reports in the Digital Data Series (DDS) distribute large amounts of data through digital media, including compact disc read-only memory (CD-ROM). They are high-quality, interpretative publications designed as self-contained packages for viewing and interpreting data and typically contain data sets, software to view the data, and explanatory text.

Water-Resources Investigations Reports are papers of an interpretative nature made available to the public outside the formal USGS publications series. Copies are produced on request (unlike formal USGS publications) and are also available for public inspection at depositories indicated in USGS catalogs.

Open-File Reports can consist of basic data, preliminary reports, and a wide range of scientific documents on USGS investigations. Open-File Reports are designed for fast release and are available for public consultation at depositories.

\section{Maps}

Geologic Quadrangle Maps (GQ's) are multicolor geologic maps on topographic bases in 7.5- or 15-minute quadrangle formats (scales mainly 1:24,000 or 1:62,500) showing bedrock, surficial, or engineering geology. Maps generally include brief texts; some maps include structure and columnar sections only.

Geophysical Investigations Maps (GP's) are on topographic or planimetric bases at various scales. They show results of geophysical investigations using gravity, magnetic, seismic, or radioactivity surveys, which provide data on subsurface structures that are of economic or geologic significance.
Miscellaneous Investigations Series Maps or Geologic Investigations Series (I's) are on planimetric or topographic bases at various scales; they present a wide variety of format and subject matter. The series also includes 7.5-minute quadrangle photogeologic maps on planimetric bases and planetary maps.

\section{Information Periodicals}

Metal Industry Indicators (MII's) is a free monthly newsletter that analyzes and forecasts the economic health of five metal industries with composite leading and coincident indexes: primary metals, steel, copper, primary and secondary aluminum, and aluminum mill products.

Mineral Industry Surveys (MIS's) are free periodic statistical and economic reports designed to provide timely statistical data on production, distribution, stocks, and consumption of significant mineral commodities. The surveys are issued monthly, quarterly, annually, or at other regular intervals, depending on the need for current data. The MIS's are published by commodity as well as by State. A series of international MIS's is also available.

Published on an annual basis, Mineral Commodity Summaries is the earliest Government publication to furnish estimates covering nonfuel mineral industry data. Data sheets contain information on the domestic industry structure, Government programs, tariffs, and 5-year salient statistics for more than 90 individual minerals and materials.

The Minerals Yearbook discusses the performance of the worldwide minerals and materials industry during a calendar year, and it provides background information to assist in interpreting that performance. The Minerals Yearbook consists of three volumes. Volume I, Metals and Minerals, contains chapters about virtually all metallic and industrial mineral commodities important to the U.S. economy. Volume II, Area Reports: Domestic, contains a chapter on the minerals industry of each of the 50 States and Puerto Rico and the Administered Islands. Volume III, Area Reports: International, is published as four separate reports. These reports collectively contain the latest available mineral data on more than 190 foreign countries and discuss the importance of minerals to the economies of these nations and the United States.

\section{Permanent Catalogs}

"Publications of the U.S. Geological Survey, 1879-1961" and "Publications of the U.S. Geological Survey, 1962 1970" are available in paperback book form and as a set of microfiche.

"Publications of the U.S. Geological Survey, 1971-1981" is available in paperback book form (two volumes, publications listing and index) and as a set of microfiche.

Annual supplements for 1982, 1983, 1984, 1985, 1986, and subsequent years are available in paperback book form. 